IZA DP No. 8877

The Role of Constitutions on Poverty:

A Cross-National Investigation

Lanse Minkler

Nishith Prakash

February 2015

Forschungsinstitut

zur Zukunft der Arbeit

Institute for the Study

of Labor 


\title{
The Role of Constitutions on Poverty: A Cross-National Investigation
}

\author{
Lanse Minkler \\ University of Connecticut \\ Nishith Prakash \\ University of Connecticut, \\ IZA, HiCN, INSIDE and CReAM
}

Discussion Paper No. 8877

February 2015

\author{
IZA \\ P.O. Box 7240 \\ 53072 Bonn \\ Germany \\ Phone: +49-228-3894-0 \\ Fax: +49-228-3894-180 \\ E-mail: iza@iza.org
}

Any opinions expressed here are those of the author(s) and not those of IZA. Research published in this series may include views on policy, but the institute itself takes no institutional policy positions. The IZA research network is committed to the IZA Guiding Principles of Research Integrity.

The Institute for the Study of Labor (IZA) in Bonn is a local and virtual international research center and a place of communication between science, politics and business. IZA is an independent nonprofit organization supported by Deutsche Post Foundation. The center is associated with the University of Bonn and offers a stimulating research environment through its international network, workshops and conferences, data service, project support, research visits and doctoral program. IZA engages in (i) original and internationally competitive research in all fields of labor economics, (ii) development of policy concepts, and (iii) dissemination of research results and concepts to the interested public.

IZA Discussion Papers often represent preliminary work and are circulated to encourage discussion. Citation of such a paper should account for its provisional character. A revised version may be available directly from the author. 


\section{ABSTRACT \\ The Role of Constitutions on Poverty: A Cross-National Investigation"}

In this paper we use novel historical data on economics and social rights from the constitutions of 201 countries and an instrument variable strategy to answer two important questions. First, do economic and social rights provisions in constitutions reduce poverty? Second, does the strength of constitutional language of the economic and social rights matter? Constitutional provisions can be framed either more weakly as directive principles or more strongly as enforceable law. We find three important results. First, we do not find an association between constitutional rights generally framed and poverty. Second, we do not find an association between economic and social rights framed as directive principles and poverty. Third, we do find a strong negative association between economic and social rights framed as enforceable law and poverty. When we use legal origins as our IV, we find evidence that this result is causal. Our results survive a variety of robustness checks. The policy implication is that constitutional provisions framed as enforceable law provide effective meta-rules with incentives for policymakers to initiate, fund, monitor and enforce poverty reduction policies.

JEL Classification: $\quad$ I24, I32, I38, O1, O38

Keywords: economic and social rights, constitutions, enforceable law, directive principles, poverty, instrumental variables, legal origin

Corresponding author:

Nishith Prakash

Department of Economics and Human Rights Institute

University of Connecticut

365 Fairfield Way

Storrs, CT 06269-1063

USA

E-mail: nishith.prakash@uconn.edu

\footnotetext{
* We thank Jorge Aguero, Resul Cesur, Elizabeth Kaletski, Susan Randolph, David Simon and seminar participants at Department of Economics and Economics and Social Rights Group at the University of Connecticut for helpful comments and suggestions. We are especially grateful to Shaznene Hussain for her help and skillful judgment in the construction of the constitutions dataset. All remaining errors are our own.
} 


\section{Introduction}

What are the best ways to reduce international poverty? Responses range from the one size fits all Washington Consensus approach for all developing countries to stabilize, privatize, and liberalize, to massive aid transfers in order to eliminate poverty traps, to the ubiquitous appeal of targeted subsidies for public goods provision, to the now popular micro interventions studied in randomized control trials. ${ }^{1}$ While diverse in methodologies and policy prescriptions, for the most part all of these approaches share the focus of changing the opportunities and incentives of the poor themselves. While we too are concerned about choices of the poor, in this paper we instead focus on the incentives and constraints of those tasked to assist the poor: the political policymakers.

Wise or clever policy interventions, whether big or small, can only work to the extent that policymakers are willing to initiate, fund, monitor and enforce them. Of course the world is full of well-intentioned policymakers who would, and who do, jump at the chance to instantiate poverty reducing policies if and when appropriate levers and resources become available. But there are also many policymakers whose poverty reducing intentions are more fragile, fleeting, indifferent or even hostile. One potential way of limiting the effects of this latter group is to add provisions into a country's constitution that constrain policymaker choices. For Instance, if a constitution includes a legally binding provision on social insurance in case of unemployment, policymakers are obligated to expend effort and resources to such policies. Constitutional provisions may not assure best practices, but they may be an important first step in many cases.

The research question we ask in this paper is: do constitutional provisions on economic

\footnotetext{
${ }^{1}$ For a good critical discussion of the Washington Consensus (and modified Washington Consensus) as recently advocated by the World Bank and IMF, see Rodrik (2006). For the role of development aid in enhancing economic growth, and to overcome poverty traps as advocated by Sachs (2005), see Tarp (2006). On a particularly influential set of micro interventions stemming from randomized control trials, see Banerjee and Duflo (2011) and the critical review by Ravallion (2012). While perhaps not as concerned with policy recommendations, there is also a vast newer literature on the roles of geography, ecology (including disease ecology), migration and institutions on historical development patterns. On this see Diamond (1997) and Spolaore and Wacziarg (2013).
} 
and social human rights reduce poverty? It is important to study poverty as an outcome for at least two reasons. First, poverty reduction is a major objective of public policy, especially in developing countries. Second, poverty rates are a tangible and frequently used measure for deprivations of well-being. According the World Bank, in 2011 approximately 2.2 billion people lived on $\$ 2$ a day or less. ${ }^{2}$ This represents a slight decline from 2.59 billion in 1981, but highlights that there is still a long way to go before the world becomes free of poverty. Thus, it remains an open question whether various economics and social rights can successfully reduce poverty.

We borrow insights from the political economy literature which notes that constitutions can constrain politicians whose utility functions are at odds with the general populaces' preferences. We focus on economic and social human rights provisions because their express purpose is to reduce poverty or to clear the obstacles that contribute to poverty. The central economic human right is to an adequate standard of living. Because constitutional provisions are meta-rules, actual policy implementation is carried out in lower level statutory law, policies and regulations, all of which can be tailored to country, region, and even subregional heterogeneities. This is where the policy ideas discussed above can come into play.

In general, regressing the poverty outcome on measures of economic and social rights will not give causal effects because of the endogeneity problem. The effects of economic and social rights on poverty is conditional on many other factors, including the degree to which the judicial and legal system will enforce constitutional law, a country's current income and population size, its credit market, and a host of other unobserved omitted variables that are correlated with the observed exogenous factors. For example, one omitted variable that we have ex-ante reason to think would be important is census population. Many countries use population measures to devise welfare policies for their residents with some resources allocated on a headcount basis. The population size of a country may also imply additional constraints on policy options. Another important omitted variable is rule of law, which

\footnotetext{
${ }^{2}$ http://www.worldbank.org/en/topic/poverty/overview accessed February 13, 2015.
} 
reflects perceptions of the extent to which agents and in particular the quality of contract enforcement, property rights, the police, and the courts, as well as the likelihood of crime and violence. In principle, this measure also reflects the degree to which a citizen has legal recourse if his or her economic and social rights are violated. All of this could have a direct impact on the government's ability to meet its constitutional obligations to reduce poverty. ${ }^{3}$ We add these control variables and further overcome the identification problems by employing an instrumental variable strategy. In particular, we use legal origin of United Kingdom as an instrument for our endogenous variable, and estimate the causal impact of economic and social rights on poverty.

To our knowledge we are the first to investigate the role of economic and social constitutional rights on poverty reduction. We implement the empirical strategy by constructing a novel historical dataset on constitutional rights for 201 countries. The data include all economic and social rights identified in the Universal Declaration of Human Rights. Crucially, we further delineate each right by strength of language. That is, we differentiate rights that use the language of desirable policy goals from those worded as enforceable law. The main explanatory variables and indices are constructed from this new data, and our main result suggests a negative and statistically significant causal relationship between economic and social human rights framed as enforceable law and poverty.

The remainder of this paper is organized as follows. Section 2 provides background on constitutions and policymaker decisions and discusses the related literature. Section 3 presents the empirical framework. Section 4 describes the data. Section 5 presents the ordinary least square results on the association between economic and social rights and poverty, while we discuss and present the instrumental variable results in Section 6. In section 7 we discuss some robustness tests, and Section 8 concludes.

\footnotetext{
${ }^{3}$ GDP is a good proxy for incomes and is related to general development and resources available to a government, while domestic credit correlates with the ability of citizens to provide the goods and services that are the subject of ESR's for themselves.
} 


\section{Background}

\subsection{Constitutions and Policymaker Decisions}

Rights establish entitlements that enable rights-holders to make claims on obliged parties. Rights can be moral, the right against enslavement at all times for instance, or they can be legal, like enforceable prohibitions against slavery in modern times. Rights-holders achieve special status because their claims trump other utility, social policy, or political considerations (Dworkin 1977). Constitutions confer legal rights that may be realized through legislation, regulation, and/or court decisions and enforcement (Guari and Brinks 2008; Boyd 2012). Most modern constitutions contain three main parts: a bill of rights, provisions on government structure and regulation, and procedures for amendment (Elster, 1995).

Constitutional theory in economics introduced the idea that constitutions matter because they establish rules that constrain policymakers (Buchanan and Brennan, 1981; North and Weingast, 1989). ${ }^{4}$ Politicians cannot be counted on to just passively implement constituent interests because, like everyone else, policymakers too have their own utility functions. Absent binding constraints, that means policymakers will indulge their tastes for their favored policies, actions, and leisure activities. Constitutional rules add constraints to the politician's utility function, thereby limiting the choice set by committing politicians to certain actions while prohibiting them from others. Should politicians attempt to circumvent the constraints, rights-holders can press their claims with the available means. If the rightsholders are successful, the constraints are binding. For example, constitutional provisions on democratic elections entitle citizens to demand that politicians provide periodic voting

\footnotetext{
${ }^{4}$ See Wibbels (2005) for a political scientist argument of constitution formation. Wibbels argues that constitutions are the product of negotiations by elites. Those elites' interests are influenced by the heterogeneity of their regional factor endowments, which in turn will establish the demand for inter-regional redistribution. Wibbels is most interested in how constitutions distribute power between state and federal government, and how (if) resources are redistributed between urban and rural interests to address wealth inequality. Of course elites try to maintain their advantage, but Wibbels notes that the game of politics is under constant pressure from losers. Interestingly, he pulls heavily from the work of economists Sokoloff and Engerman (2000), who will be discussed in the section on identification strategy.
} 
periods and processes, while constitutional provisions on the right to housing entitle citizens to prevent governments from evictions that cause homelessness. ${ }^{5}$

Statutory law can also constrain policymakers. In fact, constitutional law often preceedes and directs statutory law. But statutory law is usually more narrow, and those laws can be altered or eliminated by even transitory majorities. In contrast, constitutional rights are often broader and protected even from the majority by the judiciary and constitutional courts (Osiatynski, 2007). In part, that's why constitutions are difficult to change (amend) and thus represent only those values most deeply held by a country.

\subsection{Empirical Literature}

The empirical literature of the effects of constitutional provisions on economic outcomes is quite small. Perhaps the most well known effort in economics, Persson and Tabellini (2003) try to identify the major effects of two constitutionally mandated political institutions: presidential versus parliamentary governing systems, and majoritarian electoral rules versus proportional representation. They find that presidential and majoritarian systems have smaller governments (as measured by government spending divided by gross domestic product), majoritarian systems have smaller welfare state spending and budget deficits, and that parliamentarian government spending increases during downtime and are not reversed during booms. ${ }^{6}$

Two recent papers investigate the effect of constitutional rights on education and health outcomes. Edward and Marin (2014) explore whether including the right to education in the constitution has been related to better educational outcomes. They find that there is no evidence that including the right to education in the constitution has been associated with higher test scores. The second paper by Matsuura (2013) shows that introducing a

\footnotetext{
${ }^{5}$ See Albisa, Scott, and Tissington (2013) for cases of government complicity in forced evictions in Chicago and Mumbai, but where similar efforts were thwarted by South Africa's constitutional provision on the right to housing in Johannesburg.

${ }^{6}$ See Acemoglu (2005) for a review of this book.
} 
constitutional right to health is likely to be an effective mechanism for improving health in countries that have a high level of democratic governance. The results suggests that the introduction of a right to health in a national constitution was significantly associated with reductions in both mean infant and under-five mortality rates. The effect was large in countries with high scores for democratic governance, whereas in countries with low scores for democratic governance, approximately half of the effect of introducing a constitutional right to health was present.

Guari and Brinks' (2008) edited collection studies the constitutional experiences of five developing countries (South Africa, Brazil, India, Nigeria, and Indonesia) to see if constitutional provisions on the rights to health care and education affect health and educational outcomes. While not addressing poverty directly, the study is instructive because it identifies both constitutional successes, as well as the potential obstacles confronting successful rights realization. For instance, South Africa's constitutional right of access to health care did significantly affect government policy, especially by addressing government failures to provide antiretroviral treatments to AIDS patients. ${ }^{7}$ Most of the health cases involved the government provision of medicines. And in the context of India, from 1950-2008, Shankar and Mehta (2008) find 382 cases on health and education that made it to the High Court level or above, with applicants winning $81 \%$ of those cases. The court rulings covered reimbursement of medical expenses, the effects of pollution on public health, HIV prevention and AIDS treatment, university fees, the establishment of private schools, and mid-day school meal programs in some states. The authors note, however, that to the extent the court decisions were actually implemented, the beneficiaries belong to the lower-middle or middle

\footnotetext{
${ }^{7}$ The the post-apartheid South African Constitution is famous because its economic and social rights of housing, health, and education guarantee citizens not individual entitlements bounded by a floor, but rather equal access to those entitlements available. The corresponding duty on the government is to enact non-discriminatory policies to maximize the realization of the rights. This constitutional formulation is thus sensitive to governmental resource constraints. Still, in the much cited Grootboom case in 2000, the litigant won a decision that required the state to create a program for progressive realization of housing rights, yet for implementation reasons to be discussed Mrs. Grootboom and many of her neighbors did not receive adequate housing for years to come. See Berger (2008).
} 
classes, not the very poor.

Perhaps just as important as the successes, Guari and Brinks also address the obstacles constitutional rights successes. Naturally, reasonably well functioning democratic political institutions are important so claimants can effectively press their demands. But even then political blockages like competing demands could frustrate demand realization. For example, if a government is trying to attract foreign capital or aid from the IMF it may have to reduce social supports. Another sort of political blockage occurs in multiparty democracies when they encounter political deadlock. A second type of obstacle occurs when there is a lack of government monitoring, oversight, and commitment to judicial decisions. Courts may find it difficult to identify the correct responsible policymakers, agencies, and bureaucrats, and then to incentivize them properly. Finally, there has to be adequate infrastructure to implement court decisions. Guari and Brinks (p. 19) note that in the case of extending the provision of medicines in Brazil, the court needed only direct existing clinics and hospitals to do so. In contrast, court orders are complicated greatly when new infrastructure has to be first implemented because that imposes added burdens on (perhaps resistant) policymakers. In general, the authors think socioeconomic constitutional successes are more likely when courts are acting within a democratic political mainstream with substantial support from a host of important political actors.

Topically different, and on a more quantitative front, two recent works consider the effects of constitutional environmental provisions on environmental outcomes. Boyd (2012) examined all 92 countries where there is a constitutional environmental right to live in a healthy environment to see if the rights resulted in statutory legislation, environmental regulation, and/or lawsuits filed. Boyd (2012, pp. 251-252) finds, for instance, that (1) 78 out of 92 countries incorporated the constitutional environmental right into major legislation, (2) constitutional environmental right's have had a lesser, but growing, effect on the filing and adjudication of environmental lawsuits, (3) procedural constitutional environmental right'sthe rights to information, participation, and access to justice-are important complements to 
the right to live in a healthy environment, and (4) the constitutional environmental right to live in a healthy environment has had a lot of the intended benefits with few of the drawbacks identified by the critics. ${ }^{8}$

A recent paper by Jeffords and Minkler (2014) uses a novel data set to test whether the presence and legal strength of constitutional environmental rights are related to environmental outcomes. The outcome variables include Yale's Environmental Performance Index and some of its components. The instrumental variables analysis accounts for the possibility that a country which takes steps to protect the environment might also be more likely to constitutionalize environmental rights. The study finds that constitutions do indeed matter for positive environmental outcomes, which suggests that we should not only pay attention to the incentives confronting polluters and resource users, but also to the incentives and constraints confronting those policymakers who initiate, monitor, and enforce environmental policies.

What is missing in this nascent literature, and what we focus on, is an investigation of the relationship between constitutional rights and poverty.

\section{Empirical Framework}

We hypothesize that the degree of poverty in any given country is a function of the incentives and constraints faced by policy-makers to enact, fund, monitor, and enforce poverty reducing policies. These incentives and constraints are determined by constitutional metarules, which we measure with our country specific constitution economic and social right (ESR) provision variables. The specific constitutional provisions, education versus unemployment social insurance for instance, target policy areas most relevant for a country's

\footnotetext{
${ }^{8}$ Boyd (2012, Ch. 12 and appendix 1) also provides some simple statistical analysis. His main result uses ANOVA to compare the means of two groups of countries, those with no constitutional environmental rights, and those with a constitutional environmental right. These means are correlated with the associated means of "ecological footprints" for 2008. Boyd does find a statistically significant difference between the group means, with the CER group enjoying a lower ecological footprint.
} 
particular circumstances and poverty reduction strategies and goals. ${ }^{9}$

We first estimate the effect of ESR on poverty. Thus, the relationship between ESR and poverty might be approximated by the following equation:

$$
y_{i}=\alpha+\beta_{1} E S R_{i}+e_{i}
$$

where $y_{i}$ is a measure of poverty, i.e. percentage of the population living on less than $\$ 2$ a day in country $i, E S R_{i}$ is a dummy variable that takes the value 1 if any of the economic and social right is included in the constitution, 0 otherwise. The coefficient of primary interest is $\beta_{1}$, which gives the association of including ESR's in the constitution on poverty.

In equation (1), omitted variable bias will likely be a concern. As mentioned earlier, the effect of ESR on poverty is conditional on many other factors, including the degree to which the judicial and legal system will enforce constitutional law, a country's current income and population size, its credit market, and a host of other unobserved omitted variables that are correlated with observed exogenous factors. Many previous studies have found latitude, an exogenous factor, to be a significant determinant of economic performance, presumably because it is correlated with the country's institutions and/or ecology (and disease ecology). We further control for exogenous factors in equation (1) with Africa and Asia dummy variables.

Modifying Equation 1 to address the problem of omitted variables, we get:

$$
y_{i}=\alpha+\beta_{1} E S R_{i}+\pi X_{i}+e_{i}
$$

where $X_{i}$ is a set of control variables (e.g. census population, rule of law, domestic credit, latitude, Africa dummy, Asia dummy, and log of GDP per capita). Depending on how we construct our explanatory variable, this regression estimates to what degree ESRs associate

\footnotetext{
${ }^{9}$ Naturally we would like to measure country specific policies, including statutory laws, regulations, and policies at the federal, state and municipal levels, but we do not have this detailed information (or, even if we did, the coding technology to reliably compare such policies across countries).
} 
with poverty.

One advantage of this initial regression is that it eliminates the measurement error involved in the construction of our ESR variables. When coding each constitution of the world it is a relatively simple matter to determine only whether or not a particular ESR is included. The disadvantage, however, is that kind of coding misses a very important nuance, namely, whether an ESR is framed as a desirable goal policymakers should strive for, or, more forcefully, as the law of the land. We discuss this distinction in more detail in the next subsection.

\subsection{Does Constitutional Language Matter? Directive Principles versus Enforceable Law}

Constitutional language differs, partly to reflect intent, with most constitutional rights framed as either directive principles or as enforceable law. Directive principles suggest that the rights represent important policy goals. Economic and social rights are sometimes framed as directive principles in order to reflect their aspirational nature and to indicate that the rights should be progressively realized over time as resources and capabilities grow. ${ }^{10}$

In contrast, constitutional rights meant as enforceable law signify entitlements that are individually justiciable. A person whose enforceable law right is violated has legal recourse, ultimately through courts. ${ }^{11}$ Whether or not the right is universally fulfilled will of course

\footnotetext{
${ }^{10}$ For instance, in Sri Lanka's constitution the rights to food and housing are framed as directive principles in Article 27: "The State is pledged to establish in Sri Lanka a democratic socialist society, the objectives of which include ... the realization by all citizens of an adequate standard of living for themselves and their families, including adequate food, clothing and housing, the continuous improvement of living conditions and the full enjoyment of leisure and social and cultural opportunities."

${ }^{11}$ For example, all constitutional rights in the US were meant, and have been interpreted (eventually), as enforceable law. As another example, the rights to food and water in Bolivia are framed as enforceable law. Article 16 of the Bolivian constitution reads: "Every person has the right to water and food; The State has the obligation to guarantee food security, by means of healthy, adequate and sufficient food for the entire population." Thus, the wording here explicitly obligates the state to guarantee the right. Some constitutions include rights as both directive principles and enforceable law. For instance the Indian constitution distinguishes between fundamental (enforceable) rights and directive principles (e.g., work and education), which are explicitly defined "as not being enforceable by any court." Other constitutions containing both enforceable law and directive principle rights include Albania, Moldova, Poland, Spain and Ireland (Sadurski
} 
depend on a host of factors including especially the degree of the rule of law.

Although it is an empirical question how directive principles versus enforceable law will affect our outcome of interest, the potential channels through which the two approaches affect poverty, our key outcome variable, differ. ${ }^{12}$ First, constitutionalizing rights as directive principles impose soft constraints on policymakers. The idea is that if a country has gone through the effort to place a right in their constitution as a directive principle it was important enough for policymakers to devote effort and resources to the right's realization. Should policymakers not do so, they weaken their popularity, political power, and re-election chances (Sadurski 2002; Minkler 2009). One benefit of this approach is that it gives legislative bodies and policymakers, rather than courts, the scope to tailor the rights realization to the country's circumstances because they are better placed to make budgetary decisions based resources and social priorities (Sunstein 2004; Osiatynski 2007). Another benefit is that constitutionalizing rights as directive principles may entail less political opposition than attempting to do so as enforceable law. The cost of this approach is that policymakers are not obligated to ensure rights realization; these soft constraints may not bind.

In contrast, when constitutional rights are interpreted as enforceable law by courts that implies legal obligations and hard constraints on policymakers. These legal obligations include the obligations to (a) not interfere with citizens' enjoyment of their rights, (b) prevent others who would interfere, and (c) help fulfill the right if citizens are unable to do so themselves. Among other policies, this latter obligation refers to things like affirmative action policies in employment and disability insurance for those unable to work. Thus the primary 2002).

${ }^{12}$ Even if rights are not formally included in a constitution that does not mean that the underlying principles are unimportant to society. Non-constitutional factors include strong social norms. For example, neither social security nor free primary and secondary education are included in the US constitution, but still they are strongly supported both politically and financially. Cass Sunstein portrays President Franklin Delano Roosevelt's (FDR) initiative for a "Second Bill of Rights" for things like employment, adequate food and clothing, shelter, education, and medical care, in order to ensure the "freedom from want" as an attempt to arouse similar support without constitutionalization (Sunstein 2004). According to Sunstein, FDR believed the cost of trying to amend the US constitution would have been prohibitive because of the inevitable political battles involved. Of course the cost of not constitutionalizing the rights is that policy-makers are not obligated to ensure their realization. 
advantage of constitutionalizing rights as enforceable law is that rights realization is most ensured. The two costs of this approach have already been alluded to. First, the strict obligations imposed on politicians assures that there will be some level of political opposition. Even those policymakers who would otherwise support the rights may prefer to do so free of binding constraints that limit their options. Second, constitutional rights interpreted as enforceable law may require courts to make policy decisions, something they may be ill-suited to do. ${ }^{13}$

By differentiating constitutional rights by the strength of their language we generate a more refined implication about the effect of rights on important developmental outcomes based upon the severity of constraints imposed on policymakers. Directive principles impose soft constraints and perhaps imply weak incentives, while enforceable law imposes hard constraints and stronger incentives. The problem is that we do not have the requisite information to know whether constitutional provisions for each ES right for each country are actually enforceable law. To know that we would need to know the historical legislative, regulatory, and judicial decisions at each level (town, province, state, etc.). So instead we explore whether the strength of language of economic and social rights translates into actual poverty outcomes. We will discuss the process presently, but the idea is that strong constitutional language that explicitly mentions things like government duties is strongly correlated with enforceable law, whereas the weaker legal language of aspirational goals is more correlated with directive principles. On this basis, we distinguish the ESR's into enforceable law (EL) and directive principles (DP), by estimating the following two regressions:

$$
y_{i}=\alpha+\beta_{2} \text { Directive Principle Dummy }+\pi X_{i}+e_{i}
$$

where Directive Principle Dummy is a dummy variable that takes the value 1 if any of the

\footnotetext{
${ }^{13}$ Some may also worry that economic and social rights are not justiciable, that is, they are not judicially enforceable. This concern is addressed and convincingly dismissed by both Sunstein (2004) and Donnelly (2007).
} 
ESR is included in the constitution of the country $i$ as DP, 0 otherwise. The coefficient of primary interest is $\beta_{2}$, which gives the effect of inclusion of an ESR as DP in the constitution on poverty.

$$
y_{i}=\alpha+\beta_{3} \text { Enforceable Law Dummy }+\pi X_{i}+e_{i}
$$

where Enforceable Law Dummy is a dummy variable that takes the value 1 if any of the ESR is included in the constitution of the country $i$ as EL, 0 otherwise. The coefficient of primary interest is $\beta_{3}$, which gives the effect of inclusion of ESR as EL in the constitution on poverty.

\section{Data}

We make two important contributions by assembling and hand-coding data on various economics and social rights. First, we hand coded data on various economic and social rights for 201 countries. Second, we further distinguish each of the economics and social rights by strength of language in an effort to reflect whether the rights are enforceable law or directive principles (non-enforceable law).

We first code the following economic and social right provisions, where each variable equals 1 if the provision in included in the Constitution, Amendment or Revision, and 0 if it is not. These economic and social rights are specifically identified in the principle international human rights document the Universal Declaration of Human Rights, adopted by the UN General Assembly in 1948, and include: Adequate Standard of Living, Right to Adequate Food/Nutrition, Right to Health/Medical care, Right to Adequate Housing, Right

to Primary Education, Free Primary Education, Compulsory Primary Education, Right to Social Services, Right to Work, Right to Public Employment, Right to Just and Favorable Remuneration, Right to Social Security in the Event of Unemployment, Right to Social Security in the Event of Disability, Right to Social Security in the Event of Sickness, Right 
to Social Security in the Event of Widowhood, and Right to Social Security in the Event of Old Age. Detailed discussion on the variables and coding can be found in Appendix A.1.

\subsection{Independent Variables}

We construct five key independent variables for our empirical analysis. We first construct a "constitutional right dummy variable" that takes the value 1 if any of the above mentioned entitlement is present in the country's constitution, 0 otherwise.

Since one of the main contributions of the paper is to separate the economic and social right provisions into enforceable law and directive principles, we consider any right/entitlement as enforceable law (EL) in cases where: Any direct or explicit wording was present regarding citizens' right to take legal action should the State fail to fulfill the right/entitlement in question; A right/entitlement was referred to as legally binding upon the State; A right/entitlement was explicitly written as "guaranteed" under the constitution. Using this, we construct a "enforceable law dummy" that takes the value 1 if any of the above mentioned entitlement is present in the country's constitution, 0 otherwise. Later, as robustness tests, we further construct two variations of the enforceable law variable. The first index uses principal component analysis, called "enforceable law index" while the second one is a sum of all enforceable laws, called the "enforceable law additive index". ${ }^{14}$

A right/entitlement was considered to be Directive Principle (DP) in cases where: The existence of the right/entitlement in question was acknowledged with no further statement regarding its enforceability; a right/entitlement was explicitly referred to as a principle the State shall endeavor to fulfill; an explicit statement was included denying citizens the right to take legal action should the State fail to fulfill any social or economic rights/entitlements

\footnotetext{
${ }^{14}$ The principal components approach helps reduce dimensionality of the data, while capturing the underlying variability. It produces mutually orthogonal linear combinations (eigenvectors) of a set of variables that capture the common pattern in the data. The eigenvector that has the highest eigenvalue, (i.e. the linear combination that captures the highest variability) is the first principal component. Principal components analysis (PCA) is one of a family of techniques for taking high-dimensional data, and using the dependencies between the variables to represent it in a more tractable, lower-dimensional form, without losing too much information.
} 
enshrined in the constitution. Using this, we construct a "directive principles dummy" that takes the value 1 if any of the above mentioned entitlement is present in the country's constitution, 0 otherwise. We further construct another variation of directive principles variable using principal component analysis, called "directive principles index" and sum of all directive principles, called "directive principles additive index".

In our sample, $68 \%$ of the countries have some form of constitutional rights, while $44 \%$ of the countries have directive principles and $23 \%$ have enforceable laws in their constitutions.

\subsection{Dependent Variable}

Our main dependent variable is a measure of head count ratio. More specifically, we use $\$ 2$ a day, where the poverty head count ratio at $\$ 2$ a day (PPP) is the percentage of the population living on less than $\$ 2$ a day at 2005 international prices. Devised by economists at the World Bank, this World Development Indicator is the median poverty rate for developing countries in 2005 (World Bank 2008).

In our sample, approximately $35 \%$ of the population in under $\$ 2 /$ day.

\subsection{Control Variables}

We use various data sources to assemble our control variables, which include census population, rule of law, domestic credit, GDP per capita, latitude of the country, and Africa and Asia dummy variables. Summary statistics are reported in Table 1.

The census population data comes from UNTATS and reflects the latest available census population data. We use this variable to control for differences in headcount poverty due to country population size.

Rule of law is a World Governance Indicator that represents perceptions of the extent to which agents have confidence in and abide by the rules of society, and in particular the quality of contract enforcement, property rights, the police, and the courts, as well as the 
likelihood of crime and violence. Estimates of governance range from approximately -2.5 (weak) to 2.5 (strong) performances. While we don't refer to any formal theory, we do expect the variable's coefficient to be negative because stronger rule of law indicates better legal institutions and better prospects for poverty reduction.

Domestic credit is a World Development Indicator that measures financial resources provided to the private sector by financial corporations, as a percentage of GDP. Combined with GDP per capita, these two variables measure the degree of a country's financial and economic development. Naturally, we expect the coefficient signs to be negative for both variables.

Finally, we include three exogenous variables. It has been argued that there is a direct effect of climate on performance by many social scientists, including Montesquieu [1784] (1989), Diamond (1997), and Sachs and coauthors. Further Gallup et al. (1998) and Hall and Jones (1999) show the correlation between distance to the equator and economic performance. We measure latitude as the absolute value of the latitude of the country (i.e., a measure of distance from the equator), scaled to take values between 0 and 1 , where 0 is the equator (taken from La Porta et al. (1999)). Africa and Asia dummy variables take the value 1 if the country belongs to that continent or region, 0 otherwise. The data come from Acemoglu et al (2001); we have no sign expectations for these exogenous geographic variables.

\section{$5 \quad$ Ordinary Least Squares Results}

In Table 2 we report the OLS estimates of any constitutional ESR on poverty as estimated by equation (2). We do not find any statistically significant association between any constitutional ESR dummy and poverty. However, in the full regression with all controls (column 5) domestic credit, latitude, and log of GDP per capita are all negatively associated with poverty, while the Africa dummy is positive associated with poverty. The rule of law coefficient has the expected negative sign before including the exogenous controls, when its 
sign then switches to positive.

To start to account for differential constitutional language, in Table 3 we report the OLS regressions of the directive principles dummy on poverty as estimated by equation (3). We find the association between directive principles dummy and poverty to be positive in all specifications and statistically significant in all before we include the exogenous geographic controls, at which time it becomes statistically insignificant. This interesting result differs from the one hypothesized because it suggests that ESR's framed as desirable policy goals are positively associated with poverty. At the very least it suggests that directive principles do not provide sufficient soft constraints on policymakers to take necessary poverty reducing action.

In Table 4 we report the association between the enforceable law dummy variable and poverty estimated by equation (4). As we move from Column (1)-Column (4), we see that the association is negative and the estimated coefficient is statistically significant. However, when we include the exogenous geographic controls in Column (5), the coefficient becomes statistically insignificant. Once again, in the full regression domestic credit, latitude, and log of GDP per capita are negatively related to poverty, whereas the Africa dummy is positively associated. These results hint that constitutional language may matter for poverty outcomes.

For the OLS estimates to be consistent, however, the selection of the ESR variables should be random after controlling for the vector of observable variables in $X_{i}$. Thus, separating the causal effect of ESR from correlation on measures of poverty is not straight forward. There are number of important reasons for not interpreting this relationship as causal. There are two important empirical challenges. First, it is hard to isolate the effect of factors that influence both the decision to incorporate an economic and social right into a constitution and then later protection of that right. For example, it is possible that richer economies are better able to afford, implement, or prefer certain types of ESR's (directive principles versus enforceable law). Second, economic and social rights may also be correlated with a country's characteristics that determine key developmental outcomes, including poverty. 
Therefore, the conditional-independence assumption may be violated due to reverse causality and selection problems, and the OLS-estimates of the ESR's effect will be biased. Perhaps more important than the reverse causality problem are the many omitted determinants of poverty differences that are also correlated with the ESR variable. Thus our OLS estimates are plausibly biased upwards.

In the next section, we attempt to overcome the empirical challenges by isolating a plausibly true exogenous variation in the ESR variables by using an instrumental variable. We discuss the instrument, its justification and the main results in the next section.

\section{Instrument Variable Strategy}

In this section we will describe our instrument, legal origins, and discuss the exclusion restriction and new the estimating equations. The idea is that a country's legal origins will differentially affect the propensity to add ESR's to a constitution for poverty alleviation. The English common law tradition reduces the probability of constitutional economic and social rights provisions, while the French civil law tradition increases the probability. Constitutional framers did not choose the legal, social, and political history prior to writing a constitution; colonies did not choose their colonial masters. In order for legal origin to be a valid instrument, it must be correlated to our ESR variable and uncorrelated to the error term. We now discuss the validity of the instrument and explain why the exclusion restriction is plausible.

Why should different legal origins affect constitutions differentially? The original proponents of the importance of legal origins, Rafael La Porta, Florencio Lopez-de-Silanes, and Andrei Shleifer (and initially Robert Vishney), wanted to know the affects of legal origins on the legal rules affecting a country's financial development, particularly through investor protection, which ultimately affects a country's growth prospects. ${ }^{15}$ The authors hypothesize

\footnotetext{
${ }^{15}$ See La Porta, Lopez-de-Silanes, Shleifer, and Vishney (1997 and 1998), and La Porta, Lopez-de-Silanes, and Shleifer (2008). These authors and others have also looked at the affects of legal origins on things like
} 
that the legal processes and ideologies differ by origin. In the common law tradition of England and its former colonies, courts establish law through precedents. This judicial power and independence was desired by elites who wanted to limit the crown's power and to protect property and contracts (La Porta, Lopez-de-Silanes, and Shleifer 2008, p. 288). In contrast, the older French civil law legal tradition has its roots in Roman law, and later in the French Revolution and Napoleon's influence, and emphasizes statutes and comprehensive codes. This reading of history suggests that the revolutionaries and then Napoleon desired to use central government power in order to change property rights, and to limit court interference (La Porta, Lopez-de-Silanes, and Shleifer 2008, p. 289). ${ }^{16}$ Therefore, the English common law tradition prioritizes court precedent for lawmaking, and property rights protections, while the French civil law tradition prioritizes legal statues and codes and more active involvement of government in markets. The legal origin's proponents argue that these differences favor the common law tradition when it comes to investor protection and finance.

While the proponents' contentions are controversial (at best), what is apparent is that the common law tradition favors what is been classically called negative rights, or those that limit government action, while the civil law tradition is more permissive of positive rights, those that promote government action. ${ }^{17}$ Since economic and social rights are usually thought of as positive rights, we contend that their inclusion in constitutions is more likely, and to a greater degree, in those countries with a civil law tradition. Thus, legal origins affect the implementation of ESR's into the constitutions. Notably, Edwards and Marin (2014) also use legal origin as an instrument to investigate whether the inclusion of the right to education in constitutions affects social performance.

The originators of the theory might object that as an instrument in our first stage relegal procedure, entry regulations, labor laws, media and bank ownership, and even military conscription (see La Porta, Lopez-de-Silanes, and Shleifer 2008).

${ }^{16}$ The authors also consider the German and Scandinavian legal traditions, which are most similar to the civil law traditions, as well as the socialist legal tradition.

${ }^{17}$ Human rights scholars increasingly dispute this negative-positive right distinction because, as Henry Shue (1996) argues, all rights impose government duties to avoid depriving, protection from others who would deprive, and to aid the deprived when they cannot fulfill the right themselves. 
gression, legal origins fails to meet the exclusion restriction because it is positively correlated with investor protection and financial development, which affects growth, and ultimately $\$ 2 /$ day poverty, our dependent variable. However, there exists a compelling empirical and theoretical literature that disputes this claim. Legal scholar Kenneth Dam (2006) thinks the legal origins idea is just wrong because it is fraught with contradictions. He contends that, factually, common law countries use corporate, securities, and bankruptcy codes just like civil law countries do. Common law countries may also have historically regulated as much, or more, than civil law countries. Finally, Dam notes that the biggest land grabs in history have come in common law countries, which suggests that there is nothing intrinsic in those origins that is property respecting. After looking at time trends, Roe and Siegel (2009, p.798) add "But Dam also has going for him the basic fact that the strongest data-based case for the superiority of common law and inferiority of French civil law is for the 1990s. When one looks backward from the 1990s to the development of debt markets, common law nations regularly lack substantial financial superiority to the French civil law nations. Frequently the reverse is true. In fact, the reverse is true so often that it is as consistent with a random relationship as with any other." If it took until the 1990s for financial divergence to occur, it is unlikely that legal origins fixed decades or centuries ago is the cause. Moreover, after performing time series analysis on a sample of twenty five countries from 1995-2005, Armour, Deakin, Mollica, and Siems (2009) conclude that increases in shareholder protection is not associated with financial development over that period.

While the legal origin idea has caught on with some in finance, to explain historical patterns of development, economists favor other explanations. For example, Acemoglu, Johnson, and Robinson (2001) argue that potential mortality rates determined the colonial strategy of either settling or extracting, which in turn determined the quality of institutions left behind. If the colonists could settle with little fear of death, from malaria for instance, they would and with them came their European institutions. Thus good institutions lead to good development outcomes. Sokoloff and Engerman (2000) categorize colonial strategies in the New 
World as a function of geography and the availability of cheap labor. The soil and climate conditions of the British West Indies combined with slavery to make enormous sugar, coffee, and staple crop plantations quite profitable. This in turn led to great economic inequality, which was codified in institutions thereby assuring its persistence. In the northern US and Canadian colonies, the climate and geography were not favorable for large plantations, and so most of the migration came from relatively skilled, homogenous, labor. The resulting relative income equality was reflected in good institutions where elites could not protect their interests as easily, which led to more economic and social opportunities for most members of the population. Finally, rather than geography or institutions, Putterman and Weil (2010) focus instead on ancestry to explain comparative development. The idea is that what matters today is the percentage of the population with European roots. Those roots represent familiarity with human capital, norms and culture, which in turn affects today's economic outcomes-the greater the ancestry, the greater the equality and national income. ${ }^{18}$

To summarize, our arguments for using legal origins as an instrument for our constitutional indices are (1) legal origins are plausibly exogenous, (2) common law origins will be more hostile to the inclusion of economic and social rights provisions in constitutions, and (3) the empirical and theoretical cases for legal origins affecting important financial variables is weak. ${ }^{19}$

Thus we use the instrument United Kingdom (UK) legal origin, $Z$, which is correlated with the two endogenous variables, Directive Principle Dummy $\left(X_{1}\right)$ and Enforceable Law Dummy $\left(X_{2}\right)$, but not with the error term $e_{i}$. Formally, we require $\operatorname{Cov}\left(Z, X_{1}\right) \neq 0$ and $\operatorname{Cov}\left(Z, X_{2}\right) \neq 0$, but $\operatorname{Cov}\left(Z, e_{i}\right)=0$. Under these conditions, we will estimate a consistent

\footnotetext{
${ }^{18}$ Of course this is just a brief sampling. For a good recent review of the literature on the causes of comparative development, including the contentious geography-institutions debate, see Spolaore and Wacziarg (2013). It is perhaps noteworthy that this comprehensive review does not include legal origins as an explanatory factor.

${ }^{19}$ In a slightly different context some researchers have exploited assassinations of leaders as an exogenous shock and estimated the causal effect on growth and democracy [See Jones and Olken (2005 and 2009)]. Mobarak (2005) uses countries with a Muslim majority populations as an instrument for democracy and finds strong causal evidence that growth performance is more stable in democracies after accounting for endogeneity of democracy and simultaneity of growth and volatility.
} 
estimate of the coefficients $\beta_{4}, \beta_{5}$ on the Directive Principle Dummy and Enforceable Law Dummy, respectively, in the following two IV estimations:

$$
\begin{gathered}
y_{i}=\alpha+\beta_{4}[U K \text { Legal Origin = Directive Principle Dummy }]+\pi X_{i}+e_{i} \\
y_{i}=\alpha+\beta_{5}[U K \text { Legal Origin = Enforceable Law Dummy }]+\pi X_{i}+e_{i}
\end{gathered}
$$

We present the IV results in Tables 5 and 6 . When we instrument directive principles dummy with UK legal origin, we see that the legal origin coefficient has the expected negative sign in the first stage, and again that the coefficients on the DP dummy variables has an unexpected positive sign in each of the second stage regressions. This result seems to question the effectiveness of directive principle constitutional provisions as a poverty reducing strategy. Nevertheless, the coefficient is not statistically significant in our preferred specification including the exogenous controls (column 5), where we also estimate a weak first stage and low F-Statistic $($ F-statistic $=3.54)$.

Our main result is reported in Table 6. Instrumenting the enforceable law dummy with UK legal origin gives us a statistically significant first stage with high F-statistic in all specifications [F-statistic $=16.55$ in Column (5), our preferred specification]. Our IV results suggest a negative and statistically significant causal relationship between constitutionally framed enforceable law provisions and poverty. The size of coefficient is much larger than the OLS estimates reported in Table 3, which is not unusual and suggests that the measurement error in the ESR variables that creates attenuation bias is likely more important than reverse causality and omitted variables biases. One source of measurement error occurs because a 0, 1 dummy variable cannot capture the full scope or coverage of constitutional ES rights. For instance, in our sample there are 5.15 directive principles per constitution. And while the mean for enforceable laws is a much lower 0.77 , the range is 0 to 10 . We address this measurement problem issue further in the next section by introducing index ESR independent 
variables. Also note that, as in our OLS estimates, the measures of economic and financial development, domestic credit and GDP/capita, are statistically negatively correlated with headcount poverty. The coefficient on latitude is also negative and significant, but now both the Asia and Africa dummy variables are insignificant.

\section{Robustness}

In this section we address three potential problems. First, since we assume that countries will choose those constitutional provisions most relevant to their circumstances with the most pressing needs met first, if any constitutional provision is important, then a dummy variable works well. But it may also be the case that the number of constitutional provisions matters. So we may further ask whether more constitutional provisions are "better" in terms of poverty reduction; is there a cumulative effect? We address this question by creating constitutional indices. Second, our sample includes virtually all of the constitutions in the world, which means that we aggregate high, middle, and low income countries. High income countries are likely to be different from the others in fundamental ways, including having comparatively few people in $\$ 2 /$ day poverty. To account for these fundamental differences, we rerun our results by excluding OECD countries. Third, while the $\$ 2 /$ day headcount measure targets exactly the poverty problem we wish to study, it is calculated with both imperfect income and consumption data. As a check we use a different dependent variable that also measures deprivation, but is instead focused on longevity-the Disability Adjusted Life Year (DALY) index. An added advantage of using this dependent variable is that it addresses any lingering

concerns about meeting the exclusion restriction when using our legal origins IV in the $\$ 2 /$ day regressions.

To address the cumulative effect issue, we construct two different constitutional provisions indices. The first is an enforceable law index using the principal components approach, one advantage of which is that researcher are not required to assign weights to each component. 
The second is an additive index, which is constructed by simply adding all the enforceable laws for each country with (benign) weights of 1 attached to each. ${ }^{20}$ We report the OLS and IV results for the enforceable law index in Tables 7 and 9 respectively. Once again, our OLS results for the enforceable law index is similar to Table 4 . While we find a negative association between the enforceable law index and poverty, the estimated coefficient is not statistically significant in our preferred specification. The IV results presented in Table 9 yield a weaker first stage [F-statistic $=3.47$ in Column (5)], with a still negative, but now statistically insignificant, relationship between the enforceable law index and poverty.

The OLS and IV results for the enforceable law additive index are reported in Tables 8 and 10, respectively. We again find a negative association between the enforceable law additive index and poverty, but the estimated coefficient on this index is now statistically significant in our preferred specification. The IV results again suggest a negative and statistically significant causal relationship between constitutional provisions framed as enforceable law and poverty. The IV results presented in Table 10 do yield a slightly weaker first stage though $[$ F-statistic $=5.24$ in Column (5)]. In sum, we take this evidence to suggest that there is some cumulative effect of additional ES rights in headcount poverty reduction.

The second issue concerns including high income countries in our sample. To address that issue we rerun our regressions with just non-OECD countries (using the enforceable law dummy) and present the IV results in Tables 11. The results are quite similar to those in Table 6, including coefficient sizes. The one notable difference is that in the non-OECD sample the coefficient on the log of census population variable is not only positive, but now it is also significant. For non-OECD countries size matters: population size and head count poverty are positively associated.

Finally, to address any measurement concerns with our key dependent variable, we substitute the non-pecuniary DALY measure. This health measure comes from the World Health

\footnotetext{
${ }^{20}$ We used the same two approaches for directive principles, but since the results were similar to those found in Tables 3 and 5 we did not report them. They are available upon request.
} 
Organization, and is defined as the age-standardized disability adjusted life years per 100,000. According to WHO, "One DALY can be thought of as one lost year of 'healthy' life. The sum of these DALYs across the population, or the burden of disease can be thought of as a measurement of the gap between current health status and an ideal health situation where the entire population lives to an advanced age, free of disease and disability..." Table 12 reports our IV results using DALY and the EL dummy. These results continue to support our main findings, namely that ESR's framed as enforceable law are a statistically significant cause of reductions in deprivation, in this case non-pecuniary health deprivations. Because DALY is adjusted life years per 100,000, the coefficients are quite large. In our preferred specification with all controls, the dummy EL coefficient is highly statistically significant. But in contrast to our central results discussed earlier, the coefficient on domestic credit is no longer significant (but still negative), while the coefficient on the rule of law becomes significant in the predicted (negative) direction, and the Asia dummy variable becomes negatively significant. The coefficient on the income variable retains its statistical significance, as in our other regressions.

\section{Discussion}

In initial discussions about this research we often heard comments to the effect "many (most?) constitutions are not worth paper they are written on." We were particularly surprised to hear these sentiments from seasoned human rights scholars. The results in this paper suggest that the issue is much more subtle. ES rights as either (a) general constitutional provisions, or (b) framed as directive principles, have no statistically significant effect on poverty reduction, at least when all controls are included. In fact, it is perhaps troubling to find statistically significant positive associations between directive principles and poverty in both OLS and IV regressions when the geography controls are excluded. In contrast, when ES rights are framed as enforceable law we get the opposite result: now constitutional provi- 
sions cause poverty reduction. The general policy conclusion, therefore, is that those who are interested in headcount poverty reduction should not waste time and energy on amending constitutions with directive principles, but should instead focus solely on enforceable law provisions.

Of course there are several caveats to this claim. First, in cross-country studies we must be careful in drawing strong general conclusions about particular countries. Based on our analysis, South Africa's innovative constitutional provisions with governmental duties to provide access to health care and housing does not meet our criteria of enforceable law language (of individual rights), but we would certainly not counsel scrapping those provisions based on the results of this study. Each country will need to consider its own circumstances and history when making such decisions. Perhaps constitutional provisions framed as directive principles are sometimes an initial gateway toward enforceable law. Second, we do not consider the costs of implementation. Amending constitutions to include ESR's as enforceable law is likely to be very costly in most cases, if only because of political opposition. While the rule of law control did not appear to be significant in our results (except when using the DALY dependent variable), it is likely that any country will need sufficient legal institutions to hold policymakers accountable. This study just does not allow us to say whether it may be cheaper to grow out of headcount poverty with pro-poor growth policies. Given the caveats above, however, we would be leery about directive principles in the face of other policy options. They do not appear to be good substitutes for enforceable law, at any price.

In conclusion, while we can learn a lot about poverty reduction from micro studies using methodologies like randomized control trials, it is also important to focus on policymaker incentives to assure the implementation of those lessons learned. This study sheds light on how constitutional provisions when framed as enforceable law can provide those incentives. 


\section{References}

Albisa, Cathy, Brittany Scott, and Kate Tissington. Demolishing Housing Rights in the Name of Market Fundamentalism: The Dynamics of Displacement in the United States, India, and South Africa in Lanse Minkler (ed.) "The State of Economic and Social Human Rights: A Global Overview." Cambridge: Cambridge University Press, 2013.

Armour, John, Simon Deakin, Viviana Mollica, and Mathias Siems. "Law and Financial Development: What We Are Learning from Time-Series Evidence." BYU Law Review, 2009, 6, pp. 1435-1500.

Banerjee, Abhijit, and Esther Duflo. Poor Economics: A Radical Rethinking of the way to Fight Global Poverty. Public Affairs, 2011.

Benjamin, Jones and Benjamin A. Olken. "Do Leaders Matter? National Leadership and Growth Since World War II." The Quarterly Journal of Economics, 2005, 120 (3), pp. 835-864.

Benjamin, Jones and Benjamin A. Olken. "Hit or Miss? The Effect of Assassinations on Institutions and War." American Economic Journal: Macroeconomics, July 2009, 1 (20), pp. 55-87.

Berger, Jonathan. Litigating for Social Justice in Post-Apartheid South Africa: A Focus on Health and Education in Guari, Varun, and Daniel Brinks (ed.) "Courting Social Justice: Judicial Enforcement of Social and Economic Rights in the Developing World." Cambridge: Cambridge University Press, 2008.

Boyd, David. The Environmental Rights Revolution: A Global Study of Constitutions, Human Rights, and the Environment." Vancouver: University of British Columbia Press, 2012. 
Buchanan, J. and Brennan, G. The Reason of Rules: Constitutional Political Economy." Cambridge University Press, 1981.

Chilton, Adam, and Mila Versteeg. "Do Constitutional Rights Make a Difference?" University of Virginia School of Law, Public Law and Legal Theory Research Paper Series, 2014, pp. 2014-2043.

Dam, Kenneth. The Law-Growth Nexus: The Rule of Law and Economic Development. Washington, D.C.: Brookings Institution Press, 2006.

Daron, Acemoglu. "Constitutions, Politics, and Economics: A Review Essay on Persson and Tabellini's The Economic Effects of Constitution," Journal of Economic Literature, December 2005, XLIII pp. 1025-1048.

Daron Acemoglu, Simon Johnson, and James A. Robinson. "The Colonial Origins of Comparative Development: An Empirical Investigation." American Economic Review, December 2001, 91 (5), pp. 1369-1401.

Diamond, Jared. Guns, Germs, and Steel: The Fates of Human Societies. NY: Norton, 1997.

Dworkin, Ronald. Taking Rights Seriously. Cambridge: Harvard University Press, 1977.

Edwards, Sebastian and Alvaro G. Marin. "Constitutional Rights and Education: An International Comparative Study." NBER Working Paper No. 20475, September 2014.

Gallup, John L., Mellinger, Andrew D. and Sachs, Jeffrey D. "Geography and Economic Development." International Regional Science Review, August 1999, 22 (2), pp. 179-232.

Gallup, John L. and Sachs, Jeffrey D. "The Economic Burden of Malaria." The American Society of Tropical Medicine and Hygiene, 2001, 64 (1, 2) S, pp. 85-96. 
Guari, Varun, and Daniel Brinks. Courting Social Justice: Judicial Enforcement of Social and Economic Rights in the Developing World. Cambridge: Cambridge University Press, 2008.

Hall, Robert E. and Charles I. Jones. "Why Do Some Countries Produce So Much More Output Per Worker Than Others?" Quarterly Journal of Economics, February 1999, 114 (1), pp. 83-116.

Jeffords, Christopher, Lanse Minkler. "Do Constitutions Matter? The Effects of Constitutional Environmental Rights Provisions on Environmental Outcomes." University of Connecticut Working Paper No. 2014-16, 2014.

La Porta, Raphael, Florencio Lopez-de-Silanes, Andrei Shleifer, and Robert Vishny. "Legal Determinants of External Finance." Journal of Finance, 1997, 52 (3), pp. 1131-1150.

La Porta, Raphael, Florencio Lopez-de-Silanes, and Andrei Shleifer, and Robert Vishny. "Law and Finance." Journal of Political Economy, 1998, 106 (6), pp. 1113-1155.

La Porta, Raphael, Florencio Lopez-de-Silanes, and Andrei Shleifer. "The Economic Consequences of Legal Origins." Journal of Economic Literature, 2008, 46 (2), pp. 285-332.

Matsuura, Hiroaki. "The Effect of a Constitutional Right to Health on Population Health in 157 Countries, 1970-2007: the Role of Democratic Governance." PGDA Working Paper 10613, Program on the Global Demography of Aging, 2013.

Minkler, Lanse. "Economic Rights and Political Decision-Making." Human Rights Quarterly, 31, 2009, pp. 368-393.

Mobarak, Mushfiq A. "Democracy, Volatility, and Economic Development." The Review of Economics and Statistics, May 2005, 87 (2), pp. 348-361.

Montesquieu, Charles de Secondat. The Spirit of the Laws. New York: Cambridge University Press, [1748] 1989. 
North, Douglas C. and Weingast, Barry R. "Constitutions and Commitment: The Evolution of Institutions Governing Public Choice in Seventeenth-Century England." The Journal of Economic History, December 1989, 49 (4), pp. 803-832.

Osiatynski, Wiktor. Social and Economic Rights in a New Constitution for Poland in Andras Sajo (ed.) "Western Rights? Post-Communist Application", 1996.

Osiatynski, Wiktor. Needs Based Approach to Social and Economic Rights in Shareen Hertel and Alanson Minkler (eds.) "Economic Rights: Conceptual, Measurement and Policy Issues." New York: Cambridge University Press, 2007.

Persson, Torsten and Guido Tabellini. The Economic Effects of Constitutions. The MIT Press, 2003.

Putterman, Louis, and David Weil. "Post-1500 Population Flows and the Long-Run Determinants of Economic Growth and Inequality." Quarterly Journal of Economics, 2010, 125 (4), pp. 1627-1682.

Ravallion, Martin. "Fighting Poverty One Experiment at a Time: A Review of Abhijit Banerjee and Esther Duflo's Poor Economics: A Radical Rethinking of the Way to Fight Global Poverty." Journal of Economic Literature, 2012, 50, pp. 103-114.

Rodrik, Dani. "Goodbye Washington Consensus?" Journal of Economic Literature, 2006, 44, pp. 973-987.

Roe, Mark, and Jordan Siegal. "Finance and Politics: A Review Essay Based on Kenneth Dam's Analysis of Legal Traditions in The Law-Growth Nexus." Journal of Economic Literature, 2009, $4^{7}$ (3), pp. 781-800.

Roe, Mark, and Jordan Siegal. "Political Instability: Effects on Financial Development, Roots in the Severity of Economic Inequality." Journal of Comparative Economics, 2011, 39, pp. 279-309. 
Sachs, Jeffrey. "Investing in Development: A Practical Plan to Achieve the Millennium Development Goals." New York: United Nations Millennium Project, 2005.

Sadurski, Wojciech. "Constitutional Courts in the Process of Articulating Constitutional Rights in the Post-communist States of Central and Eastern Europe. Part II: Social and Economic Rights." European University Institute Working Paper, Law No. 2002/14, 2002.

Shankar, Shylashri, and Pratap Bhanu Mehta. Courts and Socioeconomic Rights in India in Guari, Varun, and Daniel Brinks (ed.) "Courting Social Justice: Judicial Enforcement of Social and Economic Rights in the Developing World." Cambridge: Cambridge University Press, 2008.

Shue, Henry. Basic Rights: Subsistence, Affluence, and U.S. Foreign Policy. Princeton: Princeton University Press, 1996.

Sokoloff, Kenneth, and Stanley Engerman. "Institutions, Factor Endowments, and Paths of Development in the New World." Journal of Economic Perspectives, 2000, 14 (3), pp. $217-232$.

Spolaore, Enrico, and Romain Wacziarg. "How Deep are the Roots of Economic Development." Journal of Economic Literature, 2013, 51, pp. 325-369.

Sunstein, Cass. The Second Bill of Rights: FDR's Unfinished Revolution and Why We Need It More Than Ever. New York: Basic Books, 2004

Wibbels, Erik. "Decentralized Governance, Constitution Formation, and Redistribution." Constitutional Political Economy, 2005, 16, pp. 161-188.

Tarp, Finn. "Aid and Development." Swedish Economic Policy Review, 2006, 13, pp. 9-61. 
TABLE 1

Descriptive Statistics

\section{Observations Mean Standard Deviation Minimum Maximum}

Dependent Variables

Two Dollar a Day (\% population)

119

Disability Adjusted Life Year

\section{Independent Variables}

Constitutional Rights Dummy

Directive Principle Dummy

Directive Principle Index

Directive Principle Additive Index

Enforceable Law Dummy

Enforceable Law Index

Enforceable Law Additive Index

\section{Control Variables}

Log of Census Population

Rule of Law

Domestic Credit

Latitude

Africa Dummy

Asia Dummy

Log of GDP Per Capita

\section{Instrumental Variable}

Legal Origin United Kingdom

117

189
187

34.92

24484.24

29.70

14572.53

0.47

0.50

2.32

3.85

0.42

2.24

1.78

0.44
$.06 \mathrm{E}-10$
5.15
0.23
$.88 \mathrm{E}-08$
0.77

15.29

$-0.04$

69.27

0.30

0.31

0.26

8.24

2.30

0.97

63.75

0.19

0.46

0.44

1.01

$\begin{array}{cc}9.17 & 21.02 \\ -1.94 & 1.96 \\ -65.90 & 347.30 \\ 0.00 & 0.72 \\ 0.00 & 1.00 \\ 0.00 & 1.00 \\ 5.65 & 10.03\end{array}$

$\begin{array}{cc}0.00 & 1.00 \\ 0.00 & 1.00 \\ -3.01 & 4.09 \\ 0.00 & 12.00 \\ 0.00 & 1.00 \\ -0.85 & 10.64 \\ 0.00 & 10.00\end{array}$

0.34

0.47

0.00

1.00 
TABLE 2

Association between Any Constitutional Rights and Poverty

\begin{tabular}{|c|c|c|c|c|c|}
\hline & \multicolumn{5}{|c|}{ Two Dollar A Day } \\
\hline & $(1)$ & $(2)$ & $(3)$ & $(4)$ & $(5)$ \\
\hline Constitutional Rights Dummy & $\begin{array}{c}4.797 \\
(7.885)\end{array}$ & $\begin{array}{c}3.925 \\
(8.309)\end{array}$ & $\begin{array}{l}-3.582 \\
(7.471)\end{array}$ & $\begin{array}{l}-6.177 \\
(7.478)\end{array}$ & $\begin{array}{c}0.936 \\
(4.618)\end{array}$ \\
\hline Log of Census Population & & $\begin{array}{c}0.724 \\
(1.361)\end{array}$ & $\begin{array}{c}-0.343 \\
(1.294)\end{array}$ & $\begin{array}{c}1.131 \\
(1.486)\end{array}$ & $\begin{array}{c}1.286 \\
(0.928)\end{array}$ \\
\hline Rule of Law & & & $\begin{array}{c}-21.28^{* * *} \\
(3.129)\end{array}$ & $\begin{array}{c}-15.49^{* * *} \\
(3.606)\end{array}$ & $\begin{array}{l}4.804^{*} \\
(2.527)\end{array}$ \\
\hline Domestic Credit & & & & $\begin{array}{c}-0.256^{* * *} \\
(0.0798)\end{array}$ & $\begin{array}{c}-0.0927^{* *} \\
(0.0464)\end{array}$ \\
\hline Latitude & & & & & $\begin{array}{c}-22.27^{* * *} \\
(7.719)\end{array}$ \\
\hline Africa Dummy & & & & & $\begin{array}{c}14.56 * * * \\
(5.052)\end{array}$ \\
\hline Asia Dummy & & & & & $\begin{array}{c}4.538 \\
(3.580)\end{array}$ \\
\hline Log of GDP Per Capita & & & & & $\begin{array}{c}-20.67^{* * *} \\
(2.419)\end{array}$ \\
\hline Constant & $\begin{array}{c}30.61^{* * *} \\
(7.323)\end{array}$ & $\begin{array}{c}19.78 \\
(20.41)\end{array}$ & $\begin{array}{c}33.87^{*} \\
(20.24)\end{array}$ & $\begin{array}{c}27.30 \\
(22.66)\end{array}$ & $\begin{array}{c}190.1^{* * *} \\
(22.00)\end{array}$ \\
\hline Observations & 119 & 118 & 118 & 111 & 103 \\
\hline R-squared & 0.002 & 0.004 & 0.202 & 0.280 & 0.847 \\
\hline
\end{tabular}

Notes: Robust standard errors clustered by country are reported in the parenthesis.

Asterisks denote significance levels $\left(*=.10, * *=.05,{ }^{* * *}=.01\right)$ 
TABLE 3

Association between Directive Principle and Poverty

\begin{tabular}{|c|c|c|c|c|c|}
\hline & \multicolumn{5}{|c|}{ Two Dollar A Day } \\
\hline & $(1)$ & $(2)$ & $(3)$ & $(4)$ & $(5)$ \\
\hline Directive Principle Dummy & $\begin{array}{c}16.00^{* * *} \\
(5.180)\end{array}$ & $\begin{array}{c}15.82^{* * *} \\
(5.319)\end{array}$ & $\begin{array}{c}15.20^{* * *} \\
(4.769)\end{array}$ & $\begin{array}{c}15.41^{* * *} \\
(4.634)\end{array}$ & $\begin{array}{c}2.427 \\
(2.798)\end{array}$ \\
\hline Log of Census Population & & $\begin{array}{c}0.325 \\
(1.325)\end{array}$ & $\begin{array}{c}-0.925 \\
(1.303)\end{array}$ & $\begin{array}{c}0.532 \\
(1.577)\end{array}$ & $\begin{array}{c}1.288 \\
(0.902)\end{array}$ \\
\hline Rule of Law & & & $\begin{array}{c}-20.73^{* * *} \\
(3.265)\end{array}$ & $\begin{array}{c}-15.11^{* * *} \\
(3.592)\end{array}$ & $\begin{array}{l}4.423^{*} \\
(2.551)\end{array}$ \\
\hline Domestic Credit & & & & $\begin{array}{c}-0.243^{* * *} \\
(0.0808)\end{array}$ & $\begin{array}{c}-0.0957^{* *} \\
(0.0466)\end{array}$ \\
\hline Latitude & & & & & $\begin{array}{c}-22.32^{* * * *} \\
(7.566)\end{array}$ \\
\hline Africa Dummy & & & & & $\begin{array}{c}13.45^{* * *} \\
(5.030)\end{array}$ \\
\hline Asia Dummy & & & & & $\begin{array}{c}3.511 \\
(3.597)\end{array}$ \\
\hline Log of GDP Per Capita & & & & & $\begin{array}{c}-20.49^{* * *} \\
(2.389)\end{array}$ \\
\hline Constant & $\begin{array}{c}25.38 * * * \\
(3.669)\end{array}$ & $\begin{array}{c}20.28 \\
(20.73)\end{array}$ & $\begin{array}{c}31.18 \\
(20.60)\end{array}$ & $\begin{array}{c}21.82 \\
(22.89)\end{array}$ & $\begin{array}{c}188.7^{* * *} \\
(21.35)\end{array}$ \\
\hline Observations & 119 & 118 & 118 & 111 & 103 \\
\hline R-squared & 0.070 & 0.070 & 0.263 & 0.340 & 0.848 \\
\hline
\end{tabular}

Notes: Robust standard errors clustered by country are reported in the parenthesis.

Asterisks denote significance levels $\left(*=.10,{ }^{* *}=.05,{ }^{* * *}=.01\right)$ 
TABLE 4

Association between Enforceable Law and Poverty

\begin{tabular}{|c|c|c|c|c|c|}
\hline & \multicolumn{5}{|c|}{ Two Dollar A Day } \\
\hline & (1) & $(2)$ & $(3)$ & (4) & $(5)$ \\
\hline Enforceable Law Dummy & $\begin{array}{c}-16.18^{* * *} \\
(5.358)\end{array}$ & $\begin{array}{c}-16.12^{* * *} \\
(5.424)\end{array}$ & $\begin{array}{c}-18.62^{* * *} \\
(4.715)\end{array}$ & $\begin{array}{c}-19.79^{* * *} \\
(4.526)\end{array}$ & $\begin{array}{l}-2.584 \\
(2.919)\end{array}$ \\
\hline Log of Census Population & & $\begin{array}{c}0.828 \\
(1.282)\end{array}$ & $\begin{array}{c}-0.533 \\
(1.268)\end{array}$ & $\begin{array}{c}0.906 \\
(1.503)\end{array}$ & $\begin{array}{c}1.347 \\
(0.902)\end{array}$ \\
\hline Rule of Law & & & $\begin{array}{c}-22.13^{* * *} \\
(3.176)\end{array}$ & $\begin{array}{c}-16.78^{* * *} \\
(3.387)\end{array}$ & $\begin{array}{c}4.201 \\
(2.556)\end{array}$ \\
\hline Domestic Credit & & & & $\begin{array}{c}-0.249 * * * \\
(0.0752)\end{array}$ & $\begin{array}{c}-0.0958^{* *} \\
(0.0469)\end{array}$ \\
\hline Latitude & & & & & $\begin{array}{c}-21.82^{* * * *} \\
(7.499)\end{array}$ \\
\hline Africa Dummy & & & & & $\begin{array}{l}12.95 * * \\
(5.333)\end{array}$ \\
\hline Asia Dummy & & & & & $\begin{array}{c}3.261 \\
(3.744)\end{array}$ \\
\hline Log of GDP Per Capita & & & & & $\begin{array}{c}-20.64^{* * *} \\
(2.358)\end{array}$ \\
\hline Constant & $\begin{array}{c}39.82^{* * *} \\
(3.329)\end{array}$ & $\begin{array}{c}26.56 \\
(20.41)\end{array}$ & $\begin{array}{l}38.98^{*} \\
(20.07)\end{array}$ & $\begin{array}{c}30.65 \\
(21.56)\end{array}$ & $\begin{array}{c}191.3^{* * *} \\
(21.06)\end{array}$ \\
\hline Observations & 119 & 118 & 118 & 111 & 103 \\
\hline R-squared & 0.063 & 0.065 & 0.283 & 0.370 & 0.848 \\
\hline
\end{tabular}

Notes: Robust standard errors clustered by country are reported in the parenthesis.

Asterisks denote significance levels $\left(*=.10,{ }^{* *}=.05,{ }^{* * *}=.01\right)$ 
TABLE 5

Impact of Directive Principle on Poverty

\begin{tabular}{|c|c|c|c|c|c|}
\hline \multirow[t]{2}{*}{ First Stage } & \multicolumn{5}{|c|}{ Exogenous Variable: Legal Origin UK } \\
\hline & (1) & $(2)$ & (3) & (4) & $(5)$ \\
\hline Legal Origin UK & $\begin{array}{c}-0.265^{* * *} \\
0.090\end{array}$ & $\begin{array}{c}-0.273^{* * *} \\
0.089\end{array}$ & $\begin{array}{c}-0.277^{* * *} \\
0.087\end{array}$ & $\begin{array}{c}-0.303^{* * *} \\
0.091\end{array}$ & $\begin{array}{c}-0.186 \\
0.099\end{array}$ \\
\hline $\begin{array}{l}\text { F-Statistic } \\
{[\text { Prob }>F]}\end{array}$ & $\begin{array}{c}8.64 \\
0.004\end{array}$ & $\begin{array}{c}9.43 \\
0.003\end{array}$ & $\begin{array}{l}10.03 \\
0.002\end{array}$ & $\begin{array}{l}11.01 \\
0.001\end{array}$ & $\begin{array}{c}3.54 \\
0.063\end{array}$ \\
\hline Second Stage & \multicolumn{5}{|c|}{ Two Dollar A Day } \\
\hline Directive Principle Dummy & $\begin{array}{c}72.12^{* * *} \\
(27.46)\end{array}$ & $\begin{array}{c}72.28^{* * *} \\
(27.21)\end{array}$ & $\begin{array}{c}80.37^{* * * *} \\
(29.12)\end{array}$ & $\begin{array}{c}86.25^{* * *} \\
(26.99)\end{array}$ & $\begin{array}{c}40.85 \\
(26.79)\end{array}$ \\
\hline Log of Census Population & & $\begin{array}{l}-1.543 \\
(2.234)\end{array}$ & $\begin{array}{l}-3.009 \\
(2.485)\end{array}$ & $\begin{array}{l}-1.505 \\
(2.930)\end{array}$ & $\begin{array}{c}0.972 \\
(1.440)\end{array}$ \\
\hline Rule of Law & & & $\begin{array}{c}-19.56^{* * *} \\
(6.489)\end{array}$ & $\begin{array}{c}-15.74^{* *} \\
(7.708)\end{array}$ & $\begin{array}{l}-0.437 \\
(4.527)\end{array}$ \\
\hline Domestic Credit & & & & $\begin{array}{l}-0.196 \\
(0.141)\end{array}$ & $\begin{array}{l}-0.143^{*} \\
(0.0832)\end{array}$ \\
\hline Latitude & & & & & $\begin{array}{c}-26.08^{*} \\
(13.92)\end{array}$ \\
\hline Africa Dummy & & & & & $\begin{array}{l}-1.790 \\
(13.39)\end{array}$ \\
\hline Asia Dummy & & & & & $\begin{array}{l}-11.68 \\
(12.30)\end{array}$ \\
\hline Log of GDP Per Capita & & & & & $\begin{array}{c}-16.66^{* * * *} \\
(4.003)\end{array}$ \\
\hline Constant & $\begin{array}{l}-8.107 \\
(17.55)\end{array}$ & $\begin{array}{c}16.56 \\
(32.71)\end{array}$ & $\begin{array}{c}26.28 \\
(35.63)\end{array}$ & $\begin{array}{c}10.33 \\
(40.03)\end{array}$ & $\begin{array}{c}149.9^{* * * *} \\
(38.99)\end{array}$ \\
\hline Observations & 119 & 118 & 118 & 111 & 103 \\
\hline
\end{tabular}

Notes: Robust standard errors clustered by country are reported in the parenthesis.

Asterisks denote significance levels $\left(*=.10, * *=.05,{ }^{* * *}=.01\right)$ 
TABLE 6

Impact of Enforceable Law on Poverty

\begin{tabular}{|c|c|c|c|c|c|}
\hline \multirow[t]{2}{*}{ First Stage } & \multicolumn{5}{|c|}{ Exogenous Variable: Legal Origin UK } \\
\hline & $(1)$ & $(2)$ & $(3)$ & $(4)$ & $(5)$ \\
\hline Legal Origin UK & $\begin{array}{c}-0.419^{* * *} \\
0.054\end{array}$ & $\begin{array}{c}-0.423^{* * *} \\
0.055\end{array}$ & $\begin{array}{c}-0.419^{* * *} \\
0.056\end{array}$ & $\begin{array}{c}-0.449^{* * *} \\
0.060\end{array}$ & $\begin{array}{c}-0.300^{* * *} \\
0.074\end{array}$ \\
\hline $\begin{array}{l}\text { F-Statistic } \\
{[P r o b>F]}\end{array}$ & $\begin{array}{l}60.88 \\
0.000\end{array}$ & $\begin{array}{l}59.81 \\
0.000\end{array}$ & $\begin{array}{l}56.85 \\
0.000\end{array}$ & $\begin{array}{l}55.99 \\
0.000\end{array}$ & $\begin{array}{l}16.55 \\
0.000\end{array}$ \\
\hline Second Stage & \multicolumn{5}{|c|}{ Two Dollar A Day } \\
\hline Enforceable Law Dummy & $\begin{array}{c}-45.59^{* * *} \\
(13.93)\end{array}$ & $\begin{array}{c}-46.64^{* * *} \\
(14.12)\end{array}$ & $\begin{array}{c}-53.09^{* * *} \\
(13.43)\end{array}$ & $\begin{array}{c}-58.10^{* * *} \\
(11.48)\end{array}$ & $\begin{array}{c}-25.35^{* *} \\
(11.82)\end{array}$ \\
\hline Log of Census Population & & $\begin{array}{c}0.788 \\
(1.476)\end{array}$ & $\begin{array}{l}-0.705 \\
(1.529)\end{array}$ & $\begin{array}{c}0.772 \\
(1.782)\end{array}$ & $\begin{array}{c}1.689 \\
(1.037)\end{array}$ \\
\hline Rule of Law & & & $\begin{array}{c}-24.22 * * * \\
(4.628)\end{array}$ & $\begin{array}{c}-20.28^{* * *} \\
(5.335)\end{array}$ & $\begin{array}{l}-0.463 \\
(3.398)\end{array}$ \\
\hline Domestic Credit & & & & $\begin{array}{c}-0.241^{* * *} \\
(0.0821)\end{array}$ & $\begin{array}{c}-0.124^{* *} \\
(0.0567)\end{array}$ \\
\hline Latitude & & & & & $\begin{array}{c}-19.47^{* *} \\
(9.263)\end{array}$ \\
\hline Africa Dummy & & & & & $\begin{array}{c}0.142 \\
(9.245)\end{array}$ \\
\hline Asia Dummy & & & & & $\begin{array}{l}-7.391 \\
(6.885)\end{array}$ \\
\hline Log of GDP Per Capita & & & & & $\begin{array}{c}-19.84^{* * *} \\
(2.553)\end{array}$ \\
\hline Constant & $\begin{array}{c}48.71^{* * *} \\
(4.577)\end{array}$ & $\begin{array}{c}36.50 \\
(23.62)\end{array}$ & $\begin{array}{l}51.30^{* *} \\
(24.78)\end{array}$ & $\begin{array}{c}42.91 \\
(26.21)\end{array}$ & $\begin{array}{c}192.5^{* * *} \\
(25.21)\end{array}$ \\
\hline Observations & 119 & 118 & 118 & 111 & 103 \\
\hline
\end{tabular}

Notes: Robust standard errors clustered by country are reported in the parenthesis.

Asterisks denote significance levels $\left(*=.10, * *=.05,{ }^{* * *}=.01\right)$ 
TABLE 7

Association between Enforceable Law Index and Poverty

\begin{tabular}{|c|c|c|c|c|c|}
\hline & \multicolumn{5}{|c|}{ Two Dollar A Day } \\
\hline & (1) & $(2)$ & $(3)$ & (4) & $(5)$ \\
\hline Enforceable Law Index & $\begin{array}{c}-2.809^{* * *} \\
(0.721)\end{array}$ & $\begin{array}{c}-2.825^{* * *} \\
(0.730)\end{array}$ & $\begin{array}{c}-3.771^{* * *} \\
(0.705)\end{array}$ & $\begin{array}{c}-3.787^{* * *} \\
(0.679)\end{array}$ & $\begin{array}{c}-0.650^{*} \\
(0.374)\end{array}$ \\
\hline Log of Census Population & & $\begin{array}{c}0.995 \\
(1.321)\end{array}$ & $\begin{array}{c}-0.395 \\
(1.288)\end{array}$ & $\begin{array}{c}0.973 \\
(1.559)\end{array}$ & $\begin{array}{c}1.327 \\
(0.897)\end{array}$ \\
\hline Rule of Law & & & $\begin{array}{c}-23.46^{* * *} \\
(2.952)\end{array}$ & $\begin{array}{c}-17.74^{* * *} \\
(3.160)\end{array}$ & $\begin{array}{c}3.757 \\
(2.658)\end{array}$ \\
\hline Domestic Credit & & & & $\begin{array}{c}-0.252^{* * *} \\
(0.0767)\end{array}$ & $\begin{array}{c}-0.0988^{* *} \\
(0.0474)\end{array}$ \\
\hline Latitude & & & & & $\begin{array}{c}-21.86^{* * * *} \\
(7.440)\end{array}$ \\
\hline Africa Dummy & & & & & $\begin{array}{l}13.09 * * \\
(5.003)\end{array}$ \\
\hline Asia Dummy & & & & & $\begin{array}{c}3.731 \\
(3.491)\end{array}$ \\
\hline Log of GDP Per Capita & & & & & $\begin{array}{c}-20.35^{* * *} \\
(2.348)\end{array}$ \\
\hline Constant & $\begin{array}{c}35.57^{* * *} \\
(2.708)\end{array}$ & $\begin{array}{c}19.66 \\
(20.86)\end{array}$ & $\begin{array}{c}31.41 \\
(20.26)\end{array}$ & $\begin{array}{c}24.23 \\
(22.38)\end{array}$ & $\begin{array}{c}188.4^{* * *} \\
(21.18)\end{array}$ \\
\hline Observations & 119 & 118 & 118 & 111 & 103 \\
\hline R-squared & 0.057 & 0.061 & 0.301 & 0.381 & 0.849 \\
\hline
\end{tabular}

Notes: Robust standard errors clustered by country are reported in the parenthesis.

Asterisks denote significance levels $\left(*=.10,{ }^{* *}=.05,{ }^{* * *}=.01\right)$ 
TABLE 8

Association between Enforceable Law Additive Index and Poverty

\begin{tabular}{|c|c|c|c|c|c|}
\hline & \multicolumn{5}{|c|}{ Two Dollar A Day } \\
\hline & $(1)$ & $(2)$ & $(3)$ & $(4)$ & $(5)$ \\
\hline Enforceable Law Additive Index & $\begin{array}{c}-3.578^{* * *} \\
(1.068)\end{array}$ & $\begin{array}{c}-3.610^{* * *} \\
(1.072)\end{array}$ & $\begin{array}{c}-4.840^{* * *} \\
(0.944)\end{array}$ & $\begin{array}{c}-4.937^{* * *} \\
(0.898)\end{array}$ & $\begin{array}{l}-0.867^{*} \\
(0.479)\end{array}$ \\
\hline Log of Census Population & & $\begin{array}{c}1.039 \\
(1.307)\end{array}$ & $\begin{array}{l}-0.340 \\
(1.274)\end{array}$ & $\begin{array}{c}1.066 \\
(1.544)\end{array}$ & $\begin{array}{c}1.361 \\
(0.895)\end{array}$ \\
\hline Rule of Law & & & $\begin{array}{c}-23.54^{* * *} \\
(3.000)\end{array}$ & $\begin{array}{c}-17.86^{* * *} \\
(3.177)\end{array}$ & $\begin{array}{c}3.691 \\
(2.655)\end{array}$ \\
\hline Domestic Credit & & & & $\begin{array}{c}-0.255^{* * *} \\
(0.0766)\end{array}$ & $\begin{array}{c}-0.0997^{* *} \\
(0.0476)\end{array}$ \\
\hline Latitude & & & & & $\begin{array}{c}-21.84^{* * *} \\
(7.443)\end{array}$ \\
\hline Africa Dummy & & & & & $\begin{array}{l}12.90 * * \\
(5.036)\end{array}$ \\
\hline Asia Dummy & & & & & $\begin{array}{c}3.502 \\
(3.516)\end{array}$ \\
\hline Log of GDP Per Capita & & & & & $\begin{array}{c}-20.35^{* * *} \\
(2.345)\end{array}$ \\
\hline Constant & $\begin{array}{c}38.35^{* * *} \\
(3.025)\end{array}$ & $\begin{array}{c}21.77 \\
(20.64)\end{array}$ & $\begin{array}{l}34.26^{*} \\
(20.04)\end{array}$ & $\begin{array}{c}26.69 \\
(22.03)\end{array}$ & $\begin{array}{c}188.6^{* * *} \\
(21.14)\end{array}$ \\
\hline Observations & 119 & 118 & 118 & 111 & 103 \\
\hline R-squared & 0.058 & 0.061 & 0.303 & 0.386 & 0.849 \\
\hline
\end{tabular}

Notes: Robust standard errors clustered by country are reported in the parenthesis.

Asterisks denote significance levels $\left(*=.10,{ }^{* *}=.05,{ }^{* * *}=.01\right)$ 
TABLE 9

Impact of Enforceable Law Index on Poverty

\begin{tabular}{|c|c|c|c|c|c|}
\hline \multirow[t]{2}{*}{ First Stage } & \multicolumn{5}{|c|}{ Exogenous Variable: Legal Origin UK } \\
\hline & (1) & $(2)$ & $(3)$ & (4) & $(5)$ \\
\hline Legal Origin UK & $\begin{array}{c}-1.495^{* * *} \\
0.311\end{array}$ & $\begin{array}{c}-1.488^{* * *} \\
0.310\end{array}$ & $\begin{array}{c}-1.424^{* * *} \\
0.305\end{array}$ & $\begin{array}{c}-1.578^{* * *} \\
0.333\end{array}$ & $\begin{array}{c}-0.750^{* *} \\
0.402\end{array}$ \\
\hline $\begin{array}{l}\text { F-Statistic } \\
{[\text { Prob }>F]}\end{array}$ & $\begin{array}{l}23.08 \\
0.000\end{array}$ & $\begin{array}{l}23.09 \\
0.000\end{array}$ & $\begin{array}{l}21.86 \\
0.000\end{array}$ & $\begin{array}{l}22.41 \\
0.000\end{array}$ & $\begin{array}{c}3.47 \\
0.065 \\
\end{array}$ \\
\hline Second Stage & \multicolumn{5}{|c|}{ Two Dollar A Day } \\
\hline Enforceable Law Index & $\begin{array}{c}-12.77^{* * *} \\
(4.299)\end{array}$ & $\begin{array}{c}-13.25 * * * \\
(4.379)\end{array}$ & $\begin{array}{c}-15.61^{* * *} \\
(4.458)\end{array}$ & $\begin{array}{c}-16.54^{* * *} \\
(3.964)\end{array}$ & $\begin{array}{l}-10.15 \\
(6.266)\end{array}$ \\
\hline Log of Census Population & & $\begin{array}{c}1.534 \\
(1.791)\end{array}$ & $\begin{array}{c}-0.255 \\
(1.756)\end{array}$ & $\begin{array}{c}0.967 \\
(2.128)\end{array}$ & $\begin{array}{c}1.614 \\
(1.587)\end{array}$ \\
\hline Rule of Law & & & $\begin{array}{c}-31.18^{* * * *} \\
(6.499)\end{array}$ & $\begin{array}{c}-27.05^{* * *} \\
(7.814)\end{array}$ & $\begin{array}{l}-10.46 \\
(11.71)\end{array}$ \\
\hline Domestic Credit & & & & $\begin{array}{c}-0.250^{* * *} \\
(0.0951)\end{array}$ & $\begin{array}{r}-0.188^{* *} \\
(0.0935)\end{array}$ \\
\hline Latitude & & & & & $\begin{array}{l}-18.57 \\
(22.37)\end{array}$ \\
\hline Africa Dummy & & & & & $\begin{array}{l}-6.227 \\
(13.62)\end{array}$ \\
\hline Asia Dummy & & & & & $\begin{array}{l}-7.070 \\
(11.15)\end{array}$ \\
\hline Log of GDP Per Capita & & & & & $\begin{array}{c}-14.80^{* * * *} \\
(5.578)\end{array}$ \\
\hline Constant & $\begin{array}{c}37.88^{* * *} \\
(3.236)\end{array}$ & $\begin{array}{c}13.57 \\
(28.35)\end{array}$ & $\begin{array}{c}28.53 \\
(28.21)\end{array}$ & $\begin{array}{c}23.92 \\
(31.47)\end{array}$ & $\begin{array}{c}148.2^{* * * *} \\
(54.04)\end{array}$ \\
\hline Observations & 119 & 118 & 118 & 111 & 103 \\
\hline
\end{tabular}

Notes: Robust standard errors clustered by country are reported in the parenthesis.

Asterisks denote significance levels $\left(*=.10,{ }^{* *}=.05,{ }^{* * *}=.01\right)$ 
TABLE 10

Impact of Enforceable Law Additive Index on Poverty

\begin{tabular}{|c|c|c|c|c|c|}
\hline \multirow[t]{2}{*}{ First Stage } & \multicolumn{5}{|c|}{ Exogenous Variable: Legal Origin UK } \\
\hline & $(1)$ & $(2)$ & (3) & (4) & $(5)$ \\
\hline \multirow[t]{2}{*}{ Legal Origin UK } & $-1.326^{* * *}$ & $-1.317^{* * *}$ & $1.266^{* * *}$ & $-1.386^{* * *}$ & $-0.724^{* *}$ \\
\hline & 0.243 & 0.224 & 234908.000 & 0.255 & 0.316 \\
\hline F-Statistic & 29.79 & 30.11 & 29.06 & 29.6 & 5.24 \\
\hline$[$ Prob $>F]$ & 0.000 & 0.000 & 0.000 & 0.000 & 0.024 \\
\hline & \multirow{2}{*}{\multicolumn{5}{|c|}{ Two Dollar A Day }} \\
\hline Second Stage & \multicolumn{2}{|c|}{ Instrument Variable Estimates } & & & \\
\hline Enforceable Law Additive Index & $\begin{array}{c}-14.40^{* * *} \\
(4.685)\end{array}$ & $\begin{array}{c}-14.97^{* * *} \\
(4.758)\end{array}$ & $\begin{array}{c}-17.55^{* * *} \\
(4.721)\end{array}$ & $\begin{array}{c}-18.83^{* * *} \\
(4.120)\end{array}$ & $\begin{array}{c}-10.51^{*} \\
(5.732)\end{array}$ \\
\hline Log of Census Population & & $\begin{array}{c}1.639 \\
(1.644)\end{array}$ & $\begin{array}{c}-0.0775 \\
(1.589)\end{array}$ & $\begin{array}{c}1.323 \\
(1.941)\end{array}$ & $\begin{array}{c}1.948 \\
(1.347)\end{array}$ \\
\hline Rule of Law & & & $\begin{array}{c}-30.21^{* * *} \\
(5.935)\end{array}$ & $\begin{array}{c}-25.98^{* * *} \\
(7.001)\end{array}$ & $\begin{array}{l}-7.872 \\
(8.592)\end{array}$ \\
\hline Domestic Credit & & & & $\begin{array}{c}-0.261^{* * * *} \\
(0.0887)\end{array}$ & $\begin{array}{c}-0.177^{* *} \\
(0.0805)\end{array}$ \\
\hline Latitude & & & & & $\begin{array}{l}-19.16 \\
(17.58)\end{array}$ \\
\hline Africa Dummy & & & & & $\begin{array}{l}-3.841 \\
(11.46)\end{array}$ \\
\hline Asia Dummy & & & & & $\begin{array}{l}-7.281 \\
(9.497)\end{array}$ \\
\hline Log of GDP Per Capita & & & & & $\begin{array}{c}-16.04^{* * *} \\
(4.437)\end{array}$ \\
\hline Constant & $\begin{array}{c}48.71^{* * *} \\
(4.577)\end{array}$ & $\begin{array}{c}23.18 \\
(25.63)\end{array}$ & $\begin{array}{c}39.33 \\
(25.61)\end{array}$ & $\begin{array}{c}33.36 \\
(28.44)\end{array}$ & $\begin{array}{c}160.5^{* * *} \\
(40.61)\end{array}$ \\
\hline Observations & 119 & 118 & 118 & 111 & 103 \\
\hline
\end{tabular}

Notes: Robust standard errors clustered by country are reported in the parenthesis.

Asterisks denote significance levels $\left(*=.10,{ }^{* *}=.05,{ }^{* * *}=.01\right)$ 
TABLE 11

Impact of Enforceable Law on Poverty for Non-OECD Countries

\begin{tabular}{|c|c|c|c|c|c|c|}
\hline \multirow{2}{*}{ First Stage } & \multicolumn{6}{|c|}{ Exogenous Variable: Legal Origin UK } \\
\hline & (1) & $(2)$ & $(3)$ & (4) & (5) & \\
\hline \multirow[t]{2}{*}{ Legal Origin UK } & & $-0.442^{* * *}$ & $-0.443^{* * *}$ & $-0.441^{* * *}$ & $-0.459^{* * *}$ & $-0.296^{* * *}$ \\
\hline & & 0.057 & 0.058 & 0.062 & 0.066 & 0.072 \\
\hline F-Statistic & & 59.78 & 58.73 & 50.66 & 49.05 & 16.94 \\
\hline \multirow[t]{2}{*}[\text{Prob}>F]{} & & 0.000 & 0.000 & 0.000 & 0.000 & 0.000 \\
\hline & \multicolumn{5}{|c|}{ Two Dollar A Day } & \\
\hline Second Stage & OLS & & Instrume & at Variable & Estimate & \\
\hline Enforceable Law Dummy & $\begin{array}{l}-2.897 \\
(3.316)\end{array}$ & $\begin{array}{c}-35.80^{* * *} \\
(12.95)\end{array}$ & $\begin{array}{c}-37.18^{* * *} \\
(13.09)\end{array}$ & $\begin{array}{c}-50.88^{* * *} \\
(13.15)\end{array}$ & $\begin{array}{c}-57.62^{* * *} \\
(11.47)\end{array}$ & $\begin{array}{c}-28.14^{* *} \\
(11.95)\end{array}$ \\
\hline Log of Census Population & $\begin{array}{c}1.486 \\
(0.994)\end{array}$ & & $\begin{array}{c}1.368 \\
(1.387)\end{array}$ & $\begin{array}{c}-0.0564 \\
(1.503)\end{array}$ & $\begin{array}{c}1.648 \\
(1.787)\end{array}$ & $\begin{array}{c}2.337^{* *} \\
(1.119)\end{array}$ \\
\hline Rule of Law & $\begin{array}{c}2.881 \\
(3.160)\end{array}$ & & & $\begin{array}{c}-23.78 * * * \\
(5.533)\end{array}$ & $\begin{array}{c}-20.62^{* * * *} \\
(6.112)\end{array}$ & $\begin{array}{l}-2.210 \\
(3.940)\end{array}$ \\
\hline Domestic Credit & $\begin{array}{c}-0.0978^{* *} \\
(0.0487)\end{array}$ & & & & $\begin{array}{c}-0.258^{* * *} \\
(0.0831)\end{array}$ & $\begin{array}{c}-0.143^{* *} \\
(0.0615)\end{array}$ \\
\hline Latitude & $\begin{array}{c}-24.37^{* * * *} \\
(7.924)\end{array}$ & & & & & $\begin{array}{l}-18.79^{*} \\
(10.58)\end{array}$ \\
\hline Africa Dummy & $\begin{array}{c}12.97^{* *} \\
(5.523)\end{array}$ & & & & & $\begin{array}{l}-1.812 \\
(9.539)\end{array}$ \\
\hline Asia Dummy & $\begin{array}{c}3.582 \\
(4.090)\end{array}$ & & & & & $\begin{array}{l}-9.490 \\
(7.503)\end{array}$ \\
\hline Log of GDP Per Capita & $\begin{array}{c}-20.45^{* * *} \\
(2.388)\end{array}$ & & & & & $\begin{array}{c}-19.30^{* * *} \\
(2.675)\end{array}$ \\
\hline Constant & $\begin{array}{c}187.2^{* * * *} \\
(21.85)\end{array}$ & $\begin{array}{c}48.71^{* * *} \\
(4.577)\end{array}$ & $\begin{array}{c}27.42 \\
(22.00)\end{array}$ & $\begin{array}{l}41.29^{*} \\
(24.21)\end{array}$ & $\begin{array}{c}30.00 \\
(26.07)\end{array}$ & $\begin{array}{c}179.7^{* * * *} \\
(26.36)\end{array}$ \\
\hline Observations & 95 & 110 & 109 & 109 & 103 & 95 \\
\hline R-squared & 0.835 & & & & & \\
\hline
\end{tabular}

Notes: Robust standard errors clustered by country are reported in the parenthesis.

Asterisks denote significance levels $\left(*=.10,{ }^{* *}=.05,{ }^{* * *}=.01\right)$ 


\section{TABLE 12}

Impact of Enforceable Law on DALY

\begin{tabular}{|c|c|c|c|c|c|c|}
\hline \multirow[t]{2}{*}{ First Stage } & \multicolumn{6}{|c|}{ Exogenous Variable: Legal Origin UK } \\
\hline & (1) & $(2)$ & $(3)$ & (4) & (5) & \\
\hline \multirow[t]{2}{*}{ Legal Origin UK } & & $-0.377^{* * *}$ & $-0.389^{* * *}$ & $-0.385^{* * *}$ & $-0.381^{* * *}$ & $-0.300^{* * *}$ \\
\hline & & 0.047 & 0.051 & 0.052 & 0.056 & 0.074 \\
\hline F-Statistic & & 63.33 & 57.71 & 54.61 & 46.45 & 16.55 \\
\hline \multirow[t]{2}{*}[\text{Prob}>F]{} & & 0.000 & 0.000 & 0.000 & 0.000 & 0.000 \\
\hline & \multicolumn{5}{|c|}{$D A L Y$} & \\
\hline Second Stage & OLS & & Instrum & nt Variabl & Estimate & \\
\hline Enforceable Law Dummy & $\begin{array}{l}-338.1 \\
(1,770)\end{array}$ & $\begin{array}{c}-11,984^{*} \\
(6,473)\end{array}$ & $\begin{array}{c}-14,008^{* *} \\
(6,635)\end{array}$ & $\begin{array}{c}-19,774^{* * * *} \\
(5,494)\end{array}$ & $\begin{array}{c}-18,292^{* * *} \\
(5,338)\end{array}$ & $\begin{array}{c}-23,943^{* * *} \\
(8,941)\end{array}$ \\
\hline Log of Census Population & $\begin{array}{c}74.77 \\
(534.3)\end{array}$ & & $\begin{array}{c}878.7^{* *} \\
(412.3)\end{array}$ & $\begin{array}{l}-1.812 \\
(367.0)\end{array}$ & $\begin{array}{c}508.9 \\
(441.7)\end{array}$ & $\begin{array}{c}429.9 \\
(860.6)\end{array}$ \\
\hline Rule of Law & $\begin{array}{l}-596.8 \\
(1,846)\end{array}$ & & & $\begin{array}{c}-10,201 * * * \\
(1,015)\end{array}$ & $\begin{array}{c}-7,640^{* * *} \\
(1,297)\end{array}$ & $\begin{array}{c}-5,432^{*} \\
(3,234)\end{array}$ \\
\hline Domestic Credit & $\begin{array}{l}-57.50 \\
(41.97)\end{array}$ & & & & $\begin{array}{c}-57.55^{* * *} \\
(20.01)\end{array}$ & $\begin{array}{l}-86.38 \\
(54.25)\end{array}$ \\
\hline Latitude & $\begin{array}{c}-3,619 \\
(3,968)\end{array}$ & & & & & $\begin{array}{l}-1,186 \\
(7,730)\end{array}$ \\
\hline Africa Dummy & $\begin{array}{c}15,070 \text { *** } \\
(3,750)\end{array}$ & & & & & $\begin{array}{c}1,787 \\
(6,212)\end{array}$ \\
\hline Asia Dummy & $\begin{array}{c}1,613 \\
(2,317)\end{array}$ & & & & & $\begin{array}{c}-9,430^{*} \\
(5,476)\end{array}$ \\
\hline Log of GDP Per Capita & $\begin{array}{c}-4,586^{* * *} \\
(1,593)\end{array}$ & & & & & $\begin{array}{r}-3,756^{*} \\
(1,937)\end{array}$ \\
\hline Constant & $\begin{array}{c}63,319^{* * * *} \\
(15,127)\end{array}$ & $\begin{array}{c}27,737^{* * *} \\
(2,178)\end{array}$ & $\begin{array}{c}14,610^{* *} \\
(5,980)\end{array}$ & $\begin{array}{c}29,211^{* * *} \\
(5,790)\end{array}$ & $\begin{array}{c}24,984^{* * *} \\
(6,442)\end{array}$ & $\begin{array}{c}64,561^{* * *} \\
(20,402)\end{array}$ \\
\hline Observations & 103 & 183 & 182 & 182 & 162 & 103 \\
\hline R-squared & 0.696 & & & & & \\
\hline
\end{tabular}

Notes: Robust standard errors clustered by country are reported in the parenthesis.

Asterisks denote significance levels $\left(*=.10,{ }^{* *}=.05,{ }^{* * *}=.01\right)$ 


\section{A Appendices}

\section{A.1 Data Appendix}

\section{A.1.1 Constitutional Rights Variable Construction}

The starting point for the data on ES constitutional provisions comes from accessing individual constitutions for 201 countries from Constitution Finder, a public access web service provided by Richmond University Law School since 2006. ${ }^{21}$ Often several constitutions were available for any given country, and most are translated into English. We coded each as outlined below, with the help of translation services when necessary.

To identify the appropriate ES rights to include, we used articles 23-26 of the UDHR as our compass. Those articles, and our data, include rights to (a) work (employment) at "favourable remuneration"; (b) an adequate standard of living, comprised of (i) food, (ii) housing, (iii) medical care, (iv) necessary social services (e.g., for motherhood and childcare), and (v) social security in the event of unemployment, disability, sickness, widowhood, or old age; and (c) a free, compulsory, primary education.

Perhaps the most challenging issue was to code the strength of provisions. A provision may include language about the desirability of an adequate standard of living, say, but by itself that does not mean that it becomes legally binding on the state. While provisions best interpreted as aspirational goals may impose "soft constraints" on policy makers if ignoring them imposes costs like diminished reelection chances, clearly provisions with stronger language that courts and the legal system will enforce are more likely to be taken seriously. Because policy makers prefer laws that constrain them less (declarations pre-election to the contrary) and will devote resources to interpret language ambiguities in that direction, we only code a provision as "enforceable law" (EL) if the language is clear and strong. To be interpreted as EL the provision had to expressly say that the entitlement gave citizens the right to legal action if left unfulfilled, was legally binding on the state, or was explicitly

\footnotetext{
${ }^{21}$ http://confinder.richmond.edu
} 
guaranteed under the constitution. In contrast, the provision was coded more weakly as a "directive principle" (DP) if the right was merely acknowledged with no further mention of enforceability, described as a desirable policy goal, explicitly denied citizens to legal recourse, or was qualified in any meaningful way.

In order to minimize mistakes in coding from language ambiguities, the entire data set was coded independently by two different researchers. All told, out of 3552 provisions there were 623 initial disagreements for a disagreement rate of $17.5 \%$. Those disagreements were resolved first through discussion. In the cases of continued disagreement, the judgment of the researcher who is not a coauthor was followed. In total we were able to code the constitutions of 196 countries. As an example of how the right to health care was coded, consider the cases of Albania and Chile. The relevant article for Albania is:

Article 55

1. Citizens enjoy in an equal manner the right to health care from the state.

2. Everyone has the right to health insurance pursuant to the procedure provided by law.

"The first part of the article refers to the non-discriminatory aspect of the right. The second part indicates that the law will determine its application, meaning that the nature of health insurance will be determined by political processes. The constitution itself assures that whatever results from the political process has to be applied equally. Presumably courts will assure this, but otherwise no duties have been prescribed. Accordingly, we code this provision as a directive principle."

In contrast, consider the relevant article in Chile's constitution.

Article 19 - The Right to Protection of Health.

9. The State protects the free and egalitarian access to actions for the promotion, protection and recovery of the health and rehabilitation of the individual. The coordination and control of activities related to health shall likewise rest with the State. It is the prime duty of the State to guarantee health assistance, whether undertaken by public or private institutions, in accordance with the form and conditions set forth in the law which may establish compulsory 
health quotations. Each person shall have the right to choose, the health system he wishes to join, either State or private controlled.

This constitution too assures the non-discriminatory application of the right. But whereas the article mentions "conditions set forth in the law," it also says that the state has the duty to guarantee health assistance. That strong language should give citizens recourse to courts directly no matter any decisions made in the political processes. Accordingly, we code this provision as enforceable law.

Constitutions change in two principal ways. First, as already mentioned, they can be replaced with new ones. Second, they can be amended. To account for ES rights amendments, we employed World Constitutions Illustrated, a database launched in 2010 by legal resource publisher William S. Hein \& Co. In total, there were 22 countries with potentially relevant ES rights amendments.

\section{A.2 The Coding Process followed the rules in the following Coding Manual}

\section{A.2.1 Coding of Economic and Social Rights Articles}

- "No" indicates there was no mention of the specific economic or social right/entitlement in question

- "Yes, DP" indicates that the specific economic or social right/entitlement in question is written as expressing an ideal, aspiration, or guiding principle of the State

- "Yes, EL" indicates that the specific right/entitlement in question referred to is written as binding upon the State and is justiciable

- In the category of Primary Education alone, two additional components of the right/entitlement were considered: Is primary education compulsory and/or provided free of charge? 
* "Comp." indicates primary education is compulsory

* "Free" indicates primary education is to be provided free of charge

\section{A.2.2 Distinguishing between Directive Principle [DP] and Enforceable Law} [EL]

- Right/entitlement was considered to be Enforceable Law [EL] in cases where:

- Any direct or explicit wording was present regarding citizens' right to take legal action should the State fail to fulfill the right/entitlement in question

- A right/entitlement was referred to as legally binding upon the State

- A right/entitlement was explicitly written as "guaranteed" under the constitution

- Right/entitlement was considered to be Directive Principle [DP] in cases where:

- The existence of the right/entitlement in question was acknowledged with no further statement regarding its enforceability

- A right/entitlement was explicitly referred to as a principle the State shall endeavor to fulfill

- An explicit statement was included denying citizens the right to take legal action should the State fail to fulfill any social or economic rights/entitlements enshrined in the constitution

Note: General or overarching statements regarding the existence of social and/or economic rights were not taken as an indication of the existence of specific social and/or economic rights, as either EL or DP. Furthermore, regardless of whether references to the specific rights/entitlements were dispersed throughout the constitution or to be found in a discrete chapter on social and economic rights, items were coded as either "Yes, DP" or "Yes, EL" only if the specific right/entitlement in question was explicitly mentioned. 


\section{A.2.3 Categories of Rights and Entitlements}

- ASL (Adequate Standard of Living)- Mention of the right to a standard of living adequate for the health and well-being of citizens

- Food/Nutrition - Mention of a right to minimal/adequate food/nutrition

- Health/Medical Care - Mention of right to (at least basic) healthcare service

- Housing - Mention of the right to adequate housing

- Primary Education (If yes, is it free? compulsory?) - Mention of the right to (at least) primary education. Also, is such a right to be provided free of charge and is the citizen obliged to receive such education? In cases where free and compulsory secondary education is mentioned, but the free and compulsory nature of primary education is not explicitly stated, it can be inferred that the right to free and compulsory primary education also exists, whether as EL or DP

- Social Services (motherhood, childcare, youth) - Mention of any special protections/rights with regard to pregnant women, mothers, infants, and youth

- Employment - Mention of right to work and free choice employment

- Public Employment - Mention of right to State provided employment

- Remuneration - Mention of right to a minimum or living wage

- Social Security Unemployment* - Mention of right to social security benefits or insurance in case of unemployment

- Social Security Disability* - Mention of right to social security benefits or insurance in case of disability

- Social Security Sickness* - Mention of right to social security benefits or insurance in case of sickness/illness/incapacity 
- Social Security Widowhood* - Mention of right to social security benefits or insurance in case of widowhood/loss of household provider

- Social Security Old Age* - Mention of right to social security benefits or insurance in old age

Note: *The right to social security was also coded as "Yes" (either DP or EL) in all these cases if a comprehensive statement regarding the existence of the right to social security was present

\section{A.2.4 Coding of Relevant Amendments to Economic and Social Rights Articles}

- "No" indicates that no relevant Amendments were made to the original text of the constitution. Thus, any Articles that refer to the previously coded economic and social rights (Adequate Standard of Living, Progressively Realizable Goals, Food/Nutrition, Health/Medical Care, Housing, Primary Education, Social Services, Employment, Public Employment, Remuneration, Child Labor Ban, and Social Security) were included in the original writing of the constitution

- "Yes" indicates one or more of the following changes was made to the original text of a constitution:

- One or more of the Articles that refer to the previously coded economic and social rights was revised in such a manner as to modify the Article's meaning

- One or more of the Articles that refer to the previously coded economic and social rights was removed from the original text or a previously amended version of the constitution

- One or more of the Articles that refer to the previously coded economic and social rights was added to the original text or a previously amended version of the constitution 
- If a relevant amendment(s) is indicated, the specific Article(s) amended, the date(s) of the amendment(s), and the content of the amendment(s) are noted for each constitution

\section{A.2.5 Process of Coding using World Constitutions Illustrated Data on the HeinOnline Database}

- World Constitutions Illustrated lists the original text, amending documents, and the consolidated texts of each constitution

- All amending documents checked for any references to the previously coded economic and social rights

- Original text of the constitution then compared to consolidated text(s) to further check for any changes to Articles that refer to the previously coded economic and social rights 